\title{
O pitanjima alkoholizma i protualkoholnoga djelovanja početkom 20. stoljeća u Trojednoj Kraljevini
}

\begin{abstract}
Članak na temelju arhivskih fondova čuvanih u državnim arhivima, statističkih pokazatelja, relevantne literature, novina te članaka iz časopisa "Novi naraštaj" i "Novi život" sagledava problematiku alkoholizma i početke borbe protiv alkoholizma do 1914. godine na prostoru Kraljevine Hrvatske i Slavonije te Kraljevine Dalmacije. Pitanje ozbiljnosti alkoholizma na našim prostorima aktualizirali su Fran Gudrum Oriovčanin, Nikola Đurić i Andrija Štampar kritički sagledavši problem u svojim pisanim osvrtima te pokretanjem edicija i dvaju časopisa na tu temu. U članku se propituju uzroci pojave takvih društava, društveni stereotipi o alkoholu kao i prva statistička vrednovanja utjecaja alkoholizma na društvo. Formiranjem Društva apstinenata u Kraljevini Hrvatskoj i Slavoniji godine 1912. započeo je sustavniji formalni oblik borbe protiv alkoholizma, koji je s vremenom zaživio osnivanjem podružnica po manjim mjestima diljem Kraljevina. Vrhunac djelovanja protualkoholnoga pokreta uviđa se u organizaciji izložbe godine 1914. u Umjetničkome paviljonu kao i u sudjelovanju hrvatskoga predstavnika na IV. austrijskome antialkoholnom kongresu u Brnu.
\end{abstract}

Ključne riječi: alkohol, alkoholizam, protualkoholni pokret, Andrija Štampar, Fran Gudrum Oriovčanin

\section{Uvod}

Suvremena nam statistika može omogućiti uvid u načine konzumacije alkohola, spolne razlike pri uživanju alkoholnih pića, uživanje alkoholnih pića prema vrstama, "zemljopis" alkoholizma i slično, ali pouzdanih podataka o točnome broju alkoholičara u Republici Hrvatskoj nema. "Pretpostavlja se da u Hrvatskoj preko 300 tisuća osoba

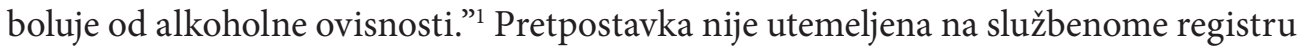
koji, iako ga je 1965. godine osnovao prof. dr. Vladimir Hudolin, nije u uporabi. Bît inercije u razumijevanju toga problema davno je uočena i vrednovana te se zasnivala

Iva Salopek Bogavčić, 10000 Zagreb, Republika Hrvatska, E-mail adresa: iva.salopek.bogavcic@ gmail.com

1 Danijela Dujmović Ojvan, Alkoholna pošast: intervju, Dr. Ivan Čelić, pristup ostvaren 30. 3. 2019., https://direktno.hr/direkt/dr-celic-za-direktno-imamo-300-tisuca-alkoholicara-najrizicnijepodrucje-je-sjeverna-hrvatska-111977/. 
na ideji nedostatka interesa države u opismenjavanju naroda o štetnosti alkohola i stvaranju protualkoholne legislative. ${ }^{2}$ Problem alkoholizma ${ }^{3}$ postoji otkako postoje i alkoholna pića, ali sustavna borba protiv toga problema novovjekovna je dvojba koja - zbog obilježja sveprisutnosti i općeprihvaćenosti - u Hrvatskoj nije razriješena ni do suvremenih dana.

Stoga je cilj ovoga rada bilo i razumijevanje kontinuirane pojave alkoholizma u hrvatskome društvu te razumijevanje kako problem alkoholizma počiva na složenim uzrocima poput tradicije pijenja alkoholnih pića, promjena poljoprivrednih kultura, običajima i stereotipima, neinformiranosti te siromaštvu društva, koji su bili potpomognuti niskim porezima i legislativom, pomanjkanjem interesa države za rješenje problema i nerazumijevanjem za suradnju s interesentima u borbi s alkoholizmom.

Modeliranju teme o alkoholizmu prethodilo je istraživanje ${ }^{4}$ o funkcioniranju kotara Nova Gradiška te povezanosti i uzajamnosti lokalnoga, regionalnoga i nacionalnoga. Na temelju rezultata istraživanja uočeno je kako se već 1906. godine u kotaru Nova Gradiška pojavio prvi protualkoholni časopis te je bilo nejasno zašto se takav časopis pojavio na lokalnoj razini a ne u nekome većem središtu? Uvidom u časopise Novi naraštaj, list za suzbijanje opojnih pića, za školu i dom ${ }^{5}$ i Novi život: glasilo Društva apstinenata u Hrvatskoj i Slavoniji ${ }^{6}$ te slične stručne edicije poput Alkohol-otrov uvidjelo se kako je pojava protualkoholnoga djelovanja bila regionalno uvjetovana te su idejni nositelji mahom bili ljudi podrijetlom iz Slavonije. O fenomenu alkoholizma krajem 19. stoljeća u hrvatskome kontekstu progovara se u novina poput Glasnik županije požeške, Narodnih novina, Radničkog Glasnika, Pokreta, Posavske Hrvatske ili Nezavisnostikao o pojavi vezanoj uz aktualizaciju poreza na alkohol ili pak o proble-

2 “Suzbijanje alkoholizma u Hrvatskoj”, Novi život: glasilo Društva apstinenata u Hrvatskoj $i$ Slavoniji (1913), br. 8: 113-121.

3 Vladimir Hudolin, Alkohološki priručnik (Zagreb: Medicinska naklada, 1991), 14. Definicija Svjetske zdravstvene organizacije iz 1951. o alkoholizmu glasi: kroničnim alkoholičarom smatra se osoba koja prekomjerno uzima alkoholna pića, u koje se razvila duševna i tjelesna ovisnost o alkoholu i koja pokazuje duševni poremećaj ili takve poremećaje ponašanja koji upućuju na oštećenja fizičkog i psihičkog zdravlja, odnosa sa drugima i poremećaj socijalnog stanja.

$4 \quad \mathrm{Rad}$ “O pitanjima alkoholizma i protualkoholnoga djelovanja početkom 20. stoljeća u Trojednoj Kraljevini” nastao je na podlozi disertacije Ive Salopek Bogavčić "Novogradiški kotar 1886. 1914." (doktorska disertacija, Sveučilište u Zagrebu, 2016). Istraživanje teme alkoholizma započeto je na primjeru kotara Nova Gradiška te su poneke spoznaje iz toga rada bile osnova za daljnja istraživanja u segmentu razumijevanja djelovanja Društva apstinenata Kraljevine Hrvatske i Slavonije. Proširenjem znanstvenih spoznaja temeljenih na neobjavljenim izvorima i novinskim člancima uvidjelo se u kojoj je mjeri djelovanje Društva apstinenata Kraljevina Hrvatske, Slavonije i Dalmacije bilo nužno i važno s obzirom na široko rasprostranjen problem alkoholizma i nove tendencije borbe protiv alkoholizma u europskome kontekstu. Započeto istraživanje problema alkoholizma i djelovanja protualkoholnoga pokreta u spomenutoj disertaciji na lokalnoj razini razrađeno je ovim radom u širemu kontekstu Kraljevina. Inovativnost članka jest u razumijevanju svih uvjetovanosti, primjerice povezanosti stereotipa o alkoholu s rasprostranjenošću alkoholizma, povezanosti bolesti vinove loze i povećane proizvodnje drugih tipova alkohola, organiziranoga djelovanja protualkoholnoga pokreta kao reakcije na rastući problem alkoholizma, ali i kao reakcije na slične trendove protualkoholnoga djelovanja u Monarhiji pa i u Europi.

5 Novi naraštaj, list za suzbijanje opojnih pića, za školu i dom (Zagreb) 1906. - 1914.

$6 \quad$ Novi život: glasilo Društva apstinenata u Hrvatskoj i Slavoniji (Karlovac) 1913. - 1921. 
mima s kojima se susreće seljaštvo. Iako se alkohol oduvijek konzumirao te Braudel $^{7}$ govori o njemu kao o velikoj inovaciji - alkoholnoj revoluciji destiliranoga alkohola, koji je proizveden u 16. stoljeću, prihvaćen u 17. stoljeću te populariziran u 18. stoljeću, problem alkoholizma tek se ozbiljnije tematizira u 19. stoljeću. Razloge tome $\mathrm{u}$ austrougarskome kontekstu treba tražiti u zakonodavnoj regulativi o proizvodnji alkohola, koja je bila pravni okvir za oporezivanje masovne industrije alkohola, pojavu moderne statistike i moderne znanosti, temeljem kojih se problemu alkoholizma počinje pristupati znanstveno, a ne samo s moralno-vjerskoga stajališta kao do tada. Pitanje koje iz toga proistječe odnosi se na razumijevanje i drugih paralelnih procesa zbog kojih je i došlo do povećanja alkoholizma. Usporednom analizom raznovrsnih izvora - poput vizualne građe, statističkih podataka i narativnih izvora - uvidjelo se u kojoj je mjeri konzumacija alkohola bila sveprisutna i opće prihvaćena pojava. Daljnji tijek istraživanja pokušao je definirati važnost stručnih protualkoholnih publikacija; tko su bili nositelji protualkoholnih ideja u Kraljevinama, ${ }^{8}$ čime su se novoosnovana udruženja građana bavila, na koje su načine organizirali svoj rad te se u radu pokušalo odgovoriti na pitanje jesu li hrvatska apstinencijska društva bila izolirana pojava ili su nastajala kao reakcija na regionalna i globalna događanja.

Konzultiranjem literature o navedenoj temi ističe se poglavlje Andrija Štampar i borba protiv alkoholizma gdje se navode elementi protualkoholnoga djelovanja Frana Gudruma Oriovčanina i Andrije Štampara od 1904. do 1953. godine s posebnim osvrtom na sustavno i kronološko navođenje njihovih knjiga i novinskih članaka na tu temu. Ukratko se tematiziraju osnovne postavke protualkoholne ideje i pokreta bez konzultacije glavnih glasila protualkoholnoga pokreta Novoga naraštaja i Novoga života. O borbi katoličkoga protualkoholnoga djelovanja pisao je Wollfy Krašić ${ }^{9}$ ukazujući na važnost kapucinskoga djelovanja i ulogu koju je slovenski katolički apstinencijski pokret imao na razvoj hrvatskoga katoličkog apstinencijskog pokreta. Taj rad nastavlja se na djelo Andreja Studena ${ }^{10}$ o moralnim i vjerskim aspektima povijesti alkoholizma u Sloveniji u kojemu autor prepoznaje začetak svjetske borbe protiv alkoholizma u djelu ljubljanskoga liječnika Franza Wilhelma Lippicha ${ }^{11}$ s početka 19. stoljeća. Na svjetskoj i europskoj razini protualkoholnu borbu istražio je već 1913. Ernest B. Gordon prateći razvoj religijskoga utjecaja, umjerenih pokreta i pojavu apstinencijskih pokreta kroz povijest. Sa sociološko-zdravstvenoga stajališta mnoštvo autora obrađivalo je problem alkoholizma,

7 Fernand Braudel, Civilization and Capitalism 15th-18th Century. Volume 1. The Structures of Everyday Life. The Limits of the Possible (London: William Collins Sons \& Co Ltd, 1985), 241.

8 U ovome će radu naglasak biti stavljen na Kraljevinu Hrvatsku i Slavoniju, uz tek pokoji osvrt na područje Kraljevine Dalmacije.

9 Wollfy Krašić, “Djelovanje kapucinskog protualkoholnog društva 'Sveta vojska”, Historijski zbornik 67 (2014), br. 1: 129-149.

10 Andrej Studen, Pijane zverine. O moralni in patološki zgodovini alkoholizma na Slovenskem $v$ dobi meščanstva (Celje: Zgodovinsko društvo, 2009).

11 Studen, Pijane zverine. Djelovanje Franza Wilhelma Lippicha još nije dovoljno rasvijetljeno, ali njegov rad zauzima pionirsko mjesto u modernome globalnom protualkoholnom djelovanju koje započinje početkom 19. stoljeća. 
ali u hrvatskome kontekstu temelje za razumijevanje toga problema u suvremenome društvu dali su Mirko Štifanić i Vladimir Hudolin.

\section{Proizvodnja alkoholnih pića u Kraljevinama Hrvatskoj, Slavoniji i Dalmaciji}

Obnova vinogradarstva zbog zapuštenosti tijekom osmanlijske vladavine započela je u Slavoniji u 18. stoljeću iako je tada proizvodnja vina bila sekundarna gospodarska grana. S vremenom su se diljem Slavonije, pogotovo na vlastelinstvima, ponovno počeli njegovati vinogradi. Prema Taubeovim zapisima Slavonac je manje sadio voćke, ali je zato više kultivirao šljivike te je rado konzumirao "Raky oder Schlivovicza,"12 a Piller i Mitterpacher ${ }^{13}$ govore kako se šljivici bolje isplate nego vinogradi te su često uređeniji od vinograda. O utjecaju alkohola na stanovništvo u Slavoniji pisao je već u 18. stoljeću Reljković opisujući zašto je uopće postojala povećana konzumacija alkohola. Upozoravajući na problem, Reljković je već tada postavio temelje razumijevanja toga problema u seoskome okruženju.

"O rakiji

Od četvrte govorit ću stvari

koja mladog domaćina kvari.

To je, druže, što kazani peku,

Pak s njih mlogi baš ništa ne steku...

jer on hranu u polju ostavi,

A kod kuće kotao nastavi,

Pak mu hrana gine i izmiče

a on često pod kazan potiče

samo da se puste nje nažvoka,

ja se čudim što mu nije žoka!

A žito mu sve stoji u polju, oko njeg se eno svinje kolju.

Tako li je, moj dragi Slavonče,

Tako li se jedna kuća teče?

jer ne ideš za čim si pošao,

neg si ovdi kazanu došao...

Jer ti voliš raditi o piću,

a nek vrane oko žita liću.

Rakija je gospodarstva dio,

kojeg, kad bi ti pametan bio,

mogao bi u novac spraviti,

pak se hranit, odiću praviti,

12 Julije Jančula, Povijest Cernika i cernička samostanska kronika (Slavonska Požega: "A. Tajkov", 1980), 201.

13 Matija Piller, Ljudevit Mitterpacher, Putovanje po Požeškoj županiji u Slavoniji 1782. god. (Požega; Osijek: Matica hrvatska, 1995), 59-64. 
kako mlogiovaj način znade pak pomalo drugim piti dade.

Al ti nećeš, neg dok kazan peče, dotle tebi i rakija teče.

Kad nestane u prosiči koma, onda nosiš prazan sudić doma

Onamo li litina ostala,

a ovako rakija nestala

ni otkud se pomagao nisi

sada gledaj siromaše gdi si?"14

Reljković je upozoravao na činjenicu da je slavonski seljak češće pribjegavao uživanju nego radu, točnije, kako nije znao unovčiti i izvore svojega užitka, nakon popijene rakije ostajao je i bez hrane o kojoj se na polju morao pobrinuti. Reljković također navodi kako su početni uzroci konzumacije alkohola često bili zbog udruživanja radi posla ${ }^{15}$ ili običaja, a poslije radi samoga uživanja, što je vodilo osiromašenju. Polovicom 19. stoljeća organiziranim djelovanjem Gospodarskoga društva i organiziranjem prvih izložbi pozornost se sve više usmjerava na kultiviranje vinograda te vino počinje biti važan proizvod. Koliko je vinarstvo bilo zastupljeno, govori i činjenica da je do godine $1864 .{ }^{16}$ na području Hrvatske i Slavonije, bivše Vojne krajine i Dalmacije bilo 2718637 rali zasađene vinove loze. U Austro-Ugarskoj nejednako su se konzumirale različite vrste alkoholnih pića ovisno o industriji pa se tako na području Bohemije i Austrijske Šleske najviše konzumiralo pivo, na području Ugarske najviše se pilo vino, dok se na području dijela Bukovine i Galicije najviše konzumirala rakija. ${ }^{17}$

Proizvodnja vina, raznih voćnih likera ${ }^{18}$ i konjaka $^{19}$ ima dugu tradiciju u Dalmaciji koja je osuvremenjivanjem strojeva, ${ }^{20}$ suvremenijim procesima destilacije i manufak-

14 Jančula, Povijest Cernika,199.

15 Kosidbe, spreže, posijela ili rad u polju.

16 Prva izložba dalmatinsko-hrvatsko-slavonska 1864. mjeseca kolovoza, rujna i listopada obdržavana u Zagrebu glavnome gradu Trojedine kraljevine (Zagreb: Antun Jakić, 1864), 32.

17 Vinko Matijević, “O policiji ćudorednosti u opće, a napose o zadatcih uprave proti alkoholizmu s osobitim obzirom na naše domaće odnošaje”, Radnički Glasnik: list za interese hrv. radničkoga staleža (Zagreb), 15. 5. 1888., 9. Već je 1877. godine donesen zakon za Galiciju i Bukovinu kojim se pokušalo utjecati na probleme alkoholizma i regulirati djelovanje gostioničara.

18 Želimir Bašić, Voda života: povijest proizvodnje jakih alkoholnih pića (Šibenik: Tiskara Malenica, 2006), 53. Tradicija proizvodnje maraskino likera u Zadru datira još iz XVI. stoljeća. Zahvaljujući znanju i kapitalu inozemnih poduzetnika iz Italije, u Splitu i Zadru otvaraju se kavane u kojima se proizvodio maraska liker. Zamah na tome području učinio je Francesco Oriolli koji je destilirao pulpu višnje i godine 1768. započinje u velikoj destileriji proizvoditi drukčiji liker nego što se do tada proizvodio.

19 Bašić, Voda života, 58. Eduard Bier imao je prvu destileriju konjaka na Sušaku, a 1868. godine već je imao podružnicu u Vukovaru. U Osijeku je Antun Bartolović 1877. godine proizvodio konjak kao i Pero Kolić u Dubrovniku.

20 Bašić, Voda života, 55-57. U Splitu već oko sredine 19. stoljeća postoji dvanaest suvremenih destilerija, među kojima se izdvaja tvornica Dalbello koja od 1849. do 1882. doživljava uspon. U Dubrovniku su također od 1830. godine postojale dvije radionice. U Šibeniku je već 1861.godine 
turnom proizvodnjom u 18./19. stoljeću dosegnula procvat. Potkraj 19. stoljeća na području Dalmacije bilo je zasađeno oko 80000 ha vinove loze i produkcija je iznosila oko 1249900 hektolitara vina. ${ }^{21}$ Vino s područja Dalmacije tijekom osamdesetih godina izvozilo se u Francusku, Češku, Austriju i Galiciju. Prema Bašiću, u Francusku se tijekom tih dvadesetak godina godišnje izvezlo oko $700000 \mathrm{hl} \mathrm{kao} \mathrm{što} \mathrm{se} \mathrm{i} \mathrm{na}$ druge prostore Austro-Ugarske izvezlo još dodatnih 150000 hl vina. ${ }^{22}$ Zbog smanjene politike obnavljanja vinograda i nedovoljno adekvatnoga čuvanja vina u Dalmaciji te oporavka od peronospore francuskoga vinogradarstva pa time i smanjenoga interesa, izvoz vina devedesetih se godina smanjivao, a pojavom peronospore ${ }^{23}$ i vinske klauzule $^{24} \mathrm{u}$ Dalmaciji razvoj vinogradarstva drastično se smanjio nakon 1894 . godine. ${ }^{25}$ Početkom stoljeća vinogradi su obnovljeni na američkoj podlozi, uvodile su se nove metode uzgoja i nove sorte, a osnivana su i razna društva kako bi se pomoglo vinogradarima. Proizvodnja likera u Dalmaciji najviše je vezana za pića Maraskino Luxardo ${ }^{26}$ i Vlahov liker. ${ }^{27}$ Oba su pića sredinom 19. stoljeća bila nagrađivana na sajmovima diljem Europe. Ugarska u drugoj polovici 19. stoljeća, zbog sve veće konkurencije s austrijskim dijelom Monarhije, potiče razvoj pojedinih oblika prehrambene industrije poput osnivanja industrija alkohola, ciglana i pivske industrije. Na području vlastelinstva Kutjeva i Daruvara te Đakovštine djelovanjem obitelji Turković, Janković i biskupa dolazi do proširenja nasada vinove loze, gradnje podruma i sve veće prisutnosti na tržištu. ${ }^{28}$

postojala tvornica Romana Vlahova kao što je i u Istri, točnije u Fažani kod Pule, djelovala tvornica alkoholnih pića Marinković.

21 M. J. Dudan, "Vina Dalmacije. Njihov sadanji i budući položaj”, Vinogradarski $i$ voćarski viestnik: ilustrovani časopis za vinogradarstvo, voćarstvo i pivničarstvo, te za promet voćem i vinom 3 (1898): 49.

22 Želimir Bašić, Dalmatinska vina kroz stoljeća: dalmatinsko vinogradarstvo i podrumarstvo $u$ rasponu vremena u legendama, umjetnosti, pravnim normama i činjenicama (Šibenik: Tiskara Kačić, 2001), 91.

23 Bašić, Dalmatinska vina, 90. Peronosporu je u Dalmaciji 1885. otkrio Pavao Zanki u vinogradima oko Zadra.

24 Bašić, Voda života, 65-66. Vinska je klauzula naziv za ugovore potpisane između Austro-Ugarske i Italije 1887. godine kojima je Italija izvozila vina u Austro-Ugarsku po nižim carinskim stopama nego u druge zemlje. Navedeni je problem trajao do 1904. godine.

25 Bašić, Voda života, 65-66. Ukupan izvoz od 1880. do1891. godine iznosio je 677700 hl, a nakon 1891. godine prestao je izvoz zbog carinske klauzule s Italijom iz 1892. kao i zbog pojave filoksere 1894. godine.

26 Bašić, Voda života, 69.

27 Bašić, Voda života, 73-78. Specifičnost eliksira Vlahov kao želučanoga eliksira bila je u činjenici da je imao ljekovita svojstva jer je bio proizveden od ljekovitih trava. Prodavao se u ljekarnama i u trgovinama likera. Ideja o ljekovitosti alkoholnih pića temelji se na uporabi ljekovitih trava pri njihovoj izradi. Propagirana ljekovita svojstva alkoholnih pića bila su osnova za ideju da alkohol liječi. Ljekovitost alkoholnih pića osobito je došla do izražaja u proizvodnji pelinkovca. Pelinkovac kao piće temeljio se na pelinu i sadržavao je tujon, ali nije, kao apsint, sadržavao veće količine pelina. Pelinkovac nije izazivao halucinacije te se zbog ovoga autohtonog proizvoda Apsinth nije u većoj mjeri nikada proizvodio u Hrvatskoj. Pelinkovac sadržava deset mg pelina po litri, dok je za sto litara Apsintha bilo potrebno $2,5 \mathrm{~kg}$ pelina.

28 Ljiljana Gašparec-Skočić, "Vinova loza i vino u povijesti, sadašnjosti i budućnosti Hrvata", Hrvatska revija 4 (2015), pristup ostvaren 10. 3. 2019. 
Devedesetih godina proizvodnja vina i alkoholnih pića u Kraljevinama Hrvatskoj i Slavoniji bila je u porastu pa je tako u razdoblju od 1880. do 1890. godine prosječno djelovalo 37913 pecara, a tijekom petogodišnjega razdoblja od 1901. do 1905. godine taj se broj smanjio na $27476 .{ }^{29} \mathrm{U}$ tome istom razdoblju proizvedeno je 15 743, 243 hektolitara žeste, a piva u sedamnaest pivovara 783870 hektolitara. ${ }^{30}$ Od 1910. do 1914. godine broj paušalnih pecara bio je stalno u padu od 25472 tijekom 1910. godine do 22723 tijekom 1914. godine, dok je broj industrijskih tvornica alkohola rastao od 19 tijekom 1910. godine do 29 tisuća tijekom 1914. godine. ${ }^{31}$

O velikome zamahu vinogradarstva devedesetih godina svjedoče i sajmovi kao i statistički podatci koji pokazuju kako je izgledalo vinogradarstvo Kraljevine prije pojave peronospore, filoksere i oidum tickerija. Industrija ${ }^{32}$ alkohola s kraja 19. stoljeća, prema Statističkome godišnjaku, dijelila se na industriju piva i slada, ${ }^{33}$ tvornice žeste, tvornice konjaka, likera i rakije te proizvodnju pjenušca. Prema Statističkome godišnjaku iz 1900. godine u Kraljevini Hrvatskoj i Slavoniji bilo je 17 industrija piva i slada, 48 tvornica žeste, 22 tvornice konjaka, likera i rakije te dva pogona za proizvodnju pjenušca. U razdoblju od 1906. do 1914. godine broj pecara žeste povećavao se od njih četiri 1907./1908. godine do 29 tijekom 1913./1914. godine. ${ }^{34}$ Koliko je god pojava peronospore i filoksere potkraj 19. stoljeća utjecala na orijentaciju s proizvodnje vina na proizvodnju rakije, piva i žestokih pića, toliko je očito da se proizvodnja žestokih pića smanjila ako se djelatne pecare ${ }^{35} \mathrm{~s}$ kraja 19. stoljeća usporede s onima početkom 20. stoljeća. Sirovine za pečenje žestokih pića bile su: "kukuruz, ostalo žito, krumpir, pečkovice i koštunjičavo voće, vinska komina, jagodasto voće, korijenje, vinsko grožđe te vino i medenica." ${ }^{36}$

Prema statističkim podatcima ${ }^{37}$ vidljivo je kako je tijekom razdoblja od 1886. do 1890. godine oko $60 \%$ zasađenih vinograda davalo pun prirod, a u vrijeme najjače rasprostranjenosti bolesti vinove loze od 1896. do 1900. godine taj se udio smanjio na oko

http://www.matica.hr/hr/470/vinova-loza-i-vino-u-povijesti-sadasnjosti-i-buducnosti-hrvata-25304/.

29 Statistički godišnjak Kraljevine Hrvatske i Slavonije I. 1905. (Zagreb: Kr. zemaljski statistički ured, 1913), 496.

$30 \quad$ Fran Gundrum Oriovčanin, Alkohol-otrov! ( Bjelovar: Lav Weiss, 1904), 5.

31 Josip Lakatoš, Industrija Hrvatske i Slavonije (Zagreb: Naklada Jugoslavenskog Lloyda, 1924), 497.

32 Milovan Zoričić, "Žiteljstvo Kraljevina Hrvatske i Slavonije po zvanju i zanimanju”, Rad JAZU, knjiga 125 (Zagreb: JAZU, 1896), 169-170. U ovome je radu termin "industrija" rabljen onako kako se njime koristio Milovan Zoričić, što bi odgovaralo suvremenome pojmu poduzetničkih pogona. Poduzetništvo se dijelilo prema broju strojeva koji se upotrebljavaju i broju radnika, tj. bez pomoćnika koji su uz vlasnika sudjelovali u radu obrta ili s pomoćnikom. Tako je postojao pogon s jednim pomoćnikom, s dva do pet pomoćnika, s više od pet, sa šest do deset pomoćnika, od jedanaest do pedeset te poduzetništvo u čijemu je pogonu djelovalo pet ili više pomoćnika.

33 Statistički godišnjak Kraljevine Hrvatske i Slavonije I., 427-438. U razdoblju od 1880. do 1905. godine broj pivovara u Kraljevinama smanjio se s 23 na 15.

34 Lakatoš, Industrija Hrvatske i Slavonije, 491.

35 Riječ je o ukupnome broju pecara žestokih pića, a ne o industrijskim postrojenjima koja su prema broju zaposlenih bila kategorizirana.

36 Statistički godišnjak Kraljevine Hrvatske i Slavonije I., 427-438.

${ }^{37}$ Statistički godišnjak Kraljevine Hrvatske i Slavonije I., 427-438. Podaci vidljivi u Tablici 1. 
10 \%. Usporedo je tekao proces smanjenja zasijanosti vinogradarskih površina te su one smanjene za oko $40 \%$ tijekom petnaestogodišnjega razdoblja pa je broj jutara s punim prirodom od 1896. do 1900. godine deset puta manji nego u razdoblju od 1886. do 1890. godine. Tek se uvođenjem američkih sorti prirod polako vraćao, ali se i stanovništvo slabije ponovno okretalo sadnji vinove loze, na što upućuje daljnje blago smanjenje površina zasađenih vinovom lozom. Prihodi od vinogradarstva povećavaju se u petogodišnjemu razdoblju od 1901. do 1905. godine iako oni još ne dosežu razdoblje prije pojave bolesti vinove loze. Iz navedenoga je vidljivo u kojoj su mjeri vinogradarski proizvodi bili traženi i skuplji tijekom razdoblja od 1901. do 1905. godine jer je tada sličan prihod ostvaren na tri puta manjoj površini punoga priroda u jutrima nego u razdoblju od 1886. do 1890. godine. ${ }^{38}$

Ako se, prema Statističkome atlasu, pogleda rasprostranjenost vinograda 1914. godine u županijama, uočava se koliko od ukupnoga tla otpada na vinograde pa je tako najviše vinograda u kotaru Irig, potom u Sv. Ivanu Zelini, Staroj Pazovi, Jastrebarskome, Zagrebu, a velik udio čine i vinogradi gradova. ${ }^{39}$ Najviše su vinograda imali gradovi Srijemski Karlovci, Petrovaradin, Brod, Bakar, Požega i Zagreb. ${ }^{40}$

Na području Zagreba početkom 19. stoljeća proizvodnjom žestokih pića bavili su se Jakow Weiss, Gracijan Mikić i Egen Sabljić, a intenzivnija proizvodnja žestokih pića započela je osnivanjem tvornice Franje Pokornyja koji je proizvodio razne, kasnije odlikovane, likere. ${ }^{41}$ U drugoj polovici 19. stoljeća u Zagrebu i okolici, to jest u Samoboru, preradom i prodajom vina bavila se tvornica Arko Zagreb kao što se time bavila i tvrtka Patria. ${ }^{42}$

\begin{tabular}{|l|l|l|l|l|l|l|l|}
\hline \multicolumn{7}{|c|}{ Vinogradarstva od 1886. do 1905. za Kraljevinu Hrvatsku i Slavoniju } \\
\hline Godine & $\begin{array}{l}\text { Ukupno } \\
\text { zasijanih } \\
\text { vinograda u } \\
\text { jutrima }\end{array}$ & $\begin{array}{l}\text { Pun } \\
\text { prirod na } \\
\text { vinogradima } \\
\text { u jutrima }\end{array}$ & $\begin{array}{l}\text { Odnos } \\
\text { zasijanoga } \\
\text { i punoga } \\
\text { priroda }\end{array}$ & $\begin{array}{l}\text { Zasijanost } \\
\text { prema } \\
\text { razdoblju } \\
1886 .-1890 .\end{array}$ & $\begin{array}{l}\text { Pun prirod } \\
\text { prema } \\
\text { razdoblju } \\
1886 .-1890 .\end{array}$ & $\begin{array}{l}\text { Prihod od } \\
\text { vinogradarstva } \\
\text { u tisućama } \\
\text { kruna }\end{array}$ & $\begin{array}{l}\text { Prihod } \\
\text { prema } \\
\text { razdoblju } \\
1886 .-1890 .\end{array}$ \\
\hline $1886 .-1890$. & 114920 & 68283 & $59,42 \%$ & $100 \%$ & $100 \%$ & $19.918 \mathrm{k}$ & $100 \%$ \\
\hline $1891 .-1895$. & 89861 & 10406 & $11,58 \%$ & $78,19 \%$ & $15,24 \%$ & $6.741 \mathrm{k}$ & $33,84 \%$ \\
\hline $1896 .-1900$. & 70490 & 6940 & $9,85 \%$ & $61,34 \%$ & $10,16 \%$ & $8.419 \mathrm{k}$ & $42,27 \%$ \\
\hline $1901 .-1905$. & 68862 & 23159 & $33,63 \%$ & $59,92 \%$ & $33,92 \%$ & $17.933 \mathrm{k}$ & $90,03 \%$ \\
\hline
\end{tabular}

Tablica 1. Vinogradarstvo Kraljevine Hrvatske i Slavonije ${ }^{43}$

38 Analize podataka autorice prema Statističkome godišnjaku Kraljevine Hrvatske i Slavonije I., 427438.

39 1875. - 1915. Statistički atlas Kraljevina Hrvatske i Slavonije (Zagreb: Tisak i litogr. Kr. zem. tiskare, 1915), 34-35.

$40 \quad$ 1875. - 1915. Statistički atlas Kraljevina Hrvatske i Slavonije, 34-35.

41 Bašić, Voda života, 61.

42 Lakatoš, Industrija Hrvatske i Slavonije, 502.

43 Tablica 1. rezultat je analize podataka autorice prema Statističkom godišnjaku Kraljevine Hrvatske i Slavonije I., 427-438. 
Pojavom peronospore ${ }^{44}$ na području Slavonije godine 1892. propali su mnogi nasadi vinove loze za što je primjer moguće naći u Požeškoj županiji. Prema Izvještaju ${ }^{45}$ županijskoga Upravnog odbora iz 1894. godine samo četvrtina svih županijskih vinograda preživjela je pojavu peronospore u Požeškoj županiji. Tijekom 1896. godine pojavila se u požeškome kraju druga bolest vinograda oidium tukeri. ${ }^{46}$ Potom se kao treća bolest grožđa u Požeštini godine 1900. pojavila filoksera. ${ }^{47}$ Od navedenih su bolesti stradali svi vinogradi, uključujući i, po proizvodnji vina poznato, kutjevačko vlastelinstvo. Tek 1902. godine cijepljenom američkom sortom grožđa u požeškome su se kraju obnovili vinogradi. Takva nešto ranija kriza i dolazak peronospore, oidium tukeri i filoksere u zemlje Ugarske Krune dovela je do uvoza vina (na primjer iz Dalmacije gdje se peronospora pojavila 1886. godine, ali znatnija stradanja loze dogodila su se zarazom filoksere tek 1894./1895. godine) pa je stoga u Kraljevinu Hrvatsku i Slavoniju izvezeno $98000 \mathrm{hl}$, a u Ugarsku $160000 \mathrm{hl}$ vina. ${ }^{48}$ Oko 1905. godine vinogradi su obnovljeni pa se, kao što i statistički podatci govore, tako prihod počeo približavati onomu prije pojave zaraznih bolesti, ali već 1907. godine Ugarska je uvela Zakon o vinu ${ }^{49}$ prema kojemu je za kvalitetu vina bila odgovorna tehnička komisija u Rijeci, koja je u svojim ocjenama bila pristrana, pa je mnoga konkurentska vina ocjenjivala kao škodljiva, to jest "krivotvorena," što je utjecalo i na trgovinu vinom.

Austrougarska država pokušala je regulirati proizvodnju alkoholnih pića prema uzoru na ostale europske zemlje. Naredba iz godine $1881 .^{50}$ bila je vezana za zabranu "krivotvorenja alkohola," ${ }^{51}$ točnije njegovu izradu od etanola ${ }^{52}$ i prodaju, a manje za konzumaciju. Tom je naredbom Vlada ograničila trgovinu etanolom i donijela zabranu uporabe etanola kao pića. Taj je zakon podržavao industrijsku proizvodnju alkohola, utjecao je na smanjenje obrtnoga pečenja rakije, a u poreznome smislu nije razlikovao proizvodnju alkoholnih pića temeljenu na tradicionalnoj proizvodnji od

44 Vladimir Anić et al., Hrvatski enciklopedijski rječnik, (Zagreb: Novi liber 2002), 939. Peronospora je bolest vinove loze kojoj su uzrok gljivice.

45 Maja Žebčević Matić, Vinogradarstvo i vinarstvo u požeškom kraju krajem 19. i početkom 20. st. Gradski muzej Požega, 18. svibnja - 15. rujna 2010.: etnografska izložba povodom Međunarodnog dana muzeja - 18. svibnja (Požega: Gradski muzej Požega, 2010), 5.

46 Jančula, Povijest Cernika, 324. Gljivična bolest vinove loze.

47 Anić, Hrvatski enciklopedijski rječnik, 345. Filoksera je trsna uš, točnije nametnik na korijenu vinove loze.

48 M. J. Dudan, "Vina Dalmacije. Njihov sadanji i budući položaj", Vinogradarski i voćarski viestnik: ilustrovani časopis za vinogradarstvo, voćarstvo i pivničarstvo, te za promet voćem i vinom 4 (1898): 66.

49 Želimir Bašić, Prošlost dalmatinskog vinarstva. Prilozi za povijest vinogradarstva, vinarstva $i$ vinarskih zadruga Hrvatske (Split: vlast. nakl., 2018), 205-206.

50 P. K., "Patvoreno piće”, Glasnik županije požeške (Požega), 21. 5. 1892., 21. Vladina naredba od 25. listopada 1881.

51 Najčešće se manipuliralo s rakijom koja bi bila izrađena od velikoga postotka etanola.

52 Salopek Bogavčić, Novogradiški kotar, 423. Pri proizvodnji alkohola velik je problem bio u njegovoj kvaliteti, točnije izradi takozvanoga krivotvorenog alkohola. Trgovci koji su proizvodili i prodavali šljivovicu imali su problema s krivotvoriteljima koji su izrađivali “šljivovicu u kućnoj radinosti”, takozvani špirit, koji je bio mješavina etanola, vode i smjese šljivova tropa/dropa. Često se proizvodila šljivovicu tako što se na šljivov drop/trop lijevao etanol pa je time stvarana razrijeđena šljivovica koja je prodavana po nižim cijenama. 
industrijske proizvodnje. ${ }^{53}$ Postojao je nekontroliran problem izrade alkoholnih pića u koja su se dodavale "ojačujuće esencije" zahvaljujući njima od jednoga kilograma dodatka moglo se napraviti tisuću litara vina. ${ }^{54}$ Problem prodaje "krivotvorenoga alkohola", izrađenoga od etanola, pokušao se riješiti uvođenjem kazni ${ }^{55}$ za gostioničare koji prodaju takva alkoholna pića. Navedena je naredba utjecala na smanjenu sadnju šljiva, a time i na smanjenje njihova uroda. Obrtnim zakonom više se pokušalo urediti točenje alkoholnih pića pa se tako članak XVII. toga zakon iz godine $1884 .{ }^{56}$ više odnosio na reguliranje prava i dozvola "krčmarenja" ${ }^{57}$ ne zadirući u regalna prava krčmarenja, ${ }^{58}$ nego na kvalitetu alkoholnih pića i porez, što je kasnijim zakonima i definirano. Obrtni zakon u članku XI. ističe nužnost stvaranja obrtnoga statuta za pojedina obrtna područja kojim bi se uredio nadzor nad obrtima koji se bave točenjem pića.

Do 1888. godine Austro-Ugarska je imala porez na alkoholna pića koji je bio manji nego u ostalim europskim zemljama te su po stanovniku plaćana 66,3 novčića, ${ }^{59}$ dok su druge zemlje imale veći porez ${ }^{60}$ čime je država pokazivala da teži u svojoj legislativi podupirati gospodarstvo, a ne modernoj legislativi koja je nastojala povisiti porez kako bi se time utjecalo na smanjenje alkoholizma. Tek novom zakonskom regulativom iz 1888. godine povećan je porez, a industrije žeste i dalje su se dijelile na industrijske i gospodarske. Zakonska je regulativa i dalje dopuštala kućnu izradu žeste od domaćih plodova i za vlastitu uporabu. Porez se plaćao paušalno i prema veličini kotla - 35 novčića po litri čistoga alkohola. ${ }^{61}$ Prema članku XXXV. Zakona iz 1888. godine $^{62}$ etilni se alkohol ponovno mogao konzumirati, što je dovelo do povećane konzumacije alkoholnih pića. Razvodnjen etilni alkohol bio je jeftiniji od šljivovice zbog čega je stanovništvo pilo manje kvalitetna alkoholna pića. ${ }^{63}$ Porez na alkohol od 1888. godine plaćao se po broju proizvedena alkohola u kotlu i po danu, točnije

53 “Opet novi porezni sustav na žestu”, Narodne Novine (Zagreb), 8. 2. 1888., 1. Riječ je o istoj poreznoj stopi.

54 "Opet novi porezni sustav na žestu”, 1.

55 P. K., "Patvoreno piće”, 21. Prva je globa iznosila 25 forinti, druga 50 forinti, a treća 100 forinti.

56 "Regalno pravo krčmarenja i zak. Čl. XVII od g. 1884. ob obrtnom zakonu”, Narodne Novine (Zagreb), 18. 10. 1888., 1.

57 Odnosi se na pravo krčmarenja prema Obrtnome zakonu iz 1884. godine.

58 Propisana Urbarom Marije Terezija (dio IV. $\$ 4$.), a poslije i potvrđena naredbom iz 1877. godine, te se odnose na točenje i posluživanje svih oblika vlastito proizvedenoga pića, osim piva koje je kupovno.

59 “Opet novi porezni sustav na žestu”, 1. Do sada je porez na hektolitar žeste iznosio jedanaest forinti, a prema novome će zakonu biti 35 forinti do razine utvrđenih kontingenata. Utvrđeni kontingent za ugarske zemlje bio je 872542 hektolitra, a za austrijske zemlje 997458 . Prijeđe li se taj utvrđeni kontingent, onda se po hektolitru čistoga alkohola oporezuje 45 forinti. Hektolitar domaće šljivovice oporezuje se 45-50 forinti, što je ista cijena za industrijski i domaći proizvod.

60 “Opet novi porezni sustav na žestu”, 1.

${ }^{61}$ Rakija je često sadržavala $50 \%$ etanola pa je onda taj porez iznosio 17 1/2 novčića po litri.

62 "Naputak o provedbi zakonskoga članka XXXV: 1888. O državnom dohodarstvu točenja pića”, Narodne novine (Zagreb), 13. 3. 1890., 1.

63 "Izkorenjujmo zlo u narodu”, Banovac, list za pouku, trgovinu, obrt i gospodarstvo (Petrinja), 21. 10. 1893., 1. 
prema tome koliko je vremena trebalo da se rakija napravi. Navedeno je utjecalo na to da je stanovništvo pokušalo ispeći što više rakije za jedan dan kako bi platilo što manje poreza. ${ }^{64}$ U Izvješćima se pojavljuju preporuke Požeške županije u vezi s tim pitanjem, koje su išle u smjeru ukidanja poreza na pečenje rakije za svoje potrebe, uz napomenu da bi se porez pokušao ubirati na drukčiji način. Time se htjelo utjecati na to da stanovništvo izrađuje kvalitetniju rakiju od čistoga voća kako bi se time manje uništavalo zdravlje. ${ }^{65}$

Zakonski članak XXXVI. iz $1890 .{ }^{66}$ godine donosi još više pogodnosti za industrijsku proizvodnju alkohola jer svi koji su prodavali žestoka pića na veliko ${ }^{67}$ trebali su samo ishoditi dozvolu od mjerodavne financijske službe. ${ }^{68}$ Time se pogodovalo industrijskoj proizvodnji žestokih pića, ali ne i proizvodnji žestokoga pića šljivovice na malo, to jest u kućnoj radinosti, koju su industrije smatrale konkurentskom prije svega u kvaliteti. Prijedlog proizvođača na malo bio je da proizvođač koji ima vlastite šljivike i proizvodi trideset hl po kotlu bude izuzet od plaćanja poreza ${ }^{69}$ jer, što se poreza tiče, isti se iznos plaćao za voćnu rakiju i apsolutni alkohol. Stvarno je stanje bilo takvo da samo proizvođač u kućnoj radinosti do jednoga hl na temelju vlastita šljivika nije plaćao porez. ${ }^{70}$ Zbog nezadovoljstva proizvođači na malo odustajali su od izrade šljivovice pa su šljivici često rezani ili se plod prodavao industriji ili pak željezničkim rutama izvozio dalje. Kvaliteta alkoholnih pića smanjivala se, a stanovništvo ih je sve više konzumiralo jer su bila sve dostupnija.

\section{Uzroci, stereotipi i statistika konzumacije alkoholnih pića}

Uzroke konzumacije alkohola i pojavu alkoholizma moguće je pronaći u raznim socijalno-ekonomskim čimbenicima. Zbog kućne proizvodnje alkoholnih pića vino i šljivovica bili su dostupna i jeftina pića te ih se često konzumiralo i kao zamjena za vodu. Glavni razlog povećane konzumacije alkoholnih pića uviđa se u pojavi industrijske proizvodnje alkohola zbog koje su alkoholna pića postala dostupnija. Podlogu povećane konzumacije sociolozi ${ }^{71}$ nalaze u neprilagođenosti, brzim promjenama, individualizmu, konkurenciji i slično, što je tipično za ruralne sredine gdje je u drugoj polovici 19. stoljeća dolazilo do intenzivnijega propadanja kućnih zadruga te time i

64 Izvješća upravnog odbora županije požeške (1903), 82. Seljaci su kriomice pekli rakiju. Porez se plaćao po veličini kotla i po danu te su, imajući lošije kotlove koje su mogli prosječno puniti tri do četiri puta na dan, morali su plaćati isti porez kao i oni koji su imali suvremenije kotlove, a punili su ih i po dvadeset puta na dan.

${ }^{65}$ Izvješća upravnog odbora županije požeške (1905), 97. Stanovništvu bi se trebalo za vlastite potrebe dopustiti da peče rakiju a da ne plate porez jer bi se na taj način radila ispravna rakija od voća ili ostataka voća, a ne sam špirit.

66 Nadopuna zakonu iz 1888. godine stupila je na snagu 14. srpnja 1890.

67 Više od sto litara.

68 Porez na žestoka alkoholna pića plaćao se na temelju paušala ili otkupa.

69 “Posljednje zasjedanje zemaljskog kulturnog vijeća”, Narodne Novine (Zagreb), 24. 10. 1891., 1.

70 “Zakon o porezu na žestu i produkciju šljivovice”, Narodne Novine (Zagreb), 12. 9. 1890., 1.

71 Mirko Štifanić, “Alkoholizam i društvene znanosti”, Društvena istraživanja 4 (1995), br. 4-5: 705. 
teže prilagodbe pojedinaca samostalnome životu. Nažalost, zbog dostupnosti i niskih cijena šljivovice seljak je često pokušao u alkoholu pronalaziti rješenje svojih problema, ali taj isti alkohol ponovno ga je, nažalost, dovodio u dug. Problem konzumacije alkohola, izrađenoga od etanola, pokušao se riješiti uvođenjem poreza kao i idejom o odustajanju od poreza na vino koje je imalo manji postotak etanola.

Alkoholna pića kao i alkoholizam do aktivnijih pojava protualkoholnoga pokreta nisu smatrani štetnima, o čemu svjedoče stereotipi koji se mogu pronaći, što u ilustrativnim materijalima, što u raznim publikacijama. Mnogi reklamni materijali na vrlo pozitivan način reklamiraju alkoholna pića stavljajući pri tom naglasak ili na proizvod i tvornicu ili na ženske osobe i djecu koja reklamiraju te proizvode. Industrija žestokih pića pojačavala je stereotipe o alkoholnim pićima kao onima koja su poželjna.

Zvekan ${ }^{72}$ karikaturom u domeni alkoholizma ismijava stereotipe, primjerice o tome kako su i liječnici i svećenici alkoholičari, ${ }^{73}$ kako gostioničari potkradaju pijanice ${ }^{74}$ te kako su žene/supruge bile nasilne prema svojim pijanim muževima (Slika 1). ${ }^{75} \mathrm{Na}$ vedeni primjeri šala - osim što ismijavaju alkoholičare - više progovaraju o društvu u kojemu stručnjaci licemjerno moraliziraju o štetnosti alkoholnih pića, a sami ih konzumiraju, o tome kako gostioničari nemaju poštovanja prema alkoholičarima, nego im je njihovo pijanstvo mimo posla i nelegalan izvor prihoda jer je lako krasti od nekoga tko nije priseban te kako žene/supruge u nemoći i nerazumijevanju bolesti alkoholizma svoje razočaranje, bijes ili tugu realiziraju kroz nasilje prema alkoholičaru-bolesniku, što govori o promijeni uloga u devijantnome ponašanju. ${ }^{76}$ Navedene karikature u ovim primjerima ukazuju na nemoć stručnjaka, gospodarstva i obitelji da se konstruktivno nose s problemom alkoholizma.

Prije Prvoga svjetskog rata u umjetničkoj domeni zanimljive su i stereotipne razglednice većih hrvatskih gradova na kojima je prikazan Noćni život u Bjelovaru ${ }^{77}$ (Slika 2), Pozdrav iz Zagreba... pijmo braćo... ${ }^{78}$, Pozdrav iz Zagreba... Pijmo ga sve do dana

72 Zvekan: humoristički list (Zagreb), 1889. do 1903.

73 "Nježan mig." Zvekan: humoristički list (1890), br.15: 113. "Biskup X dielio je u Y potvrdu, pa objedovao kod župnika Z. Biskup X bio je vrlo duhovit čovjek a župnik Z nije bio samo ljubezan čovjek, već i veliki prijatelj dobre kapljice, koje prijateljstvo nije baš osobito pritajivao. Kada su oba gospodina udobno tako sjedila kraj puna stola, kada je objed već minuo, ter su obojica još malo pijuckala, tada biskup najedanput zapita: Ma recite mi, gospodine župniče, od česa vam li je nos tako crven? - Hm, Hm, promuca župnik u neprilici. To vam dolazi Preuzvišenosti od šnofanja, pa od same neprilike napuni prazne čase. Tako, tako, odvrati na to biskup, uzme za tim svoju čašu, kucne sa župnikom i reče: Nut, pa prošnjofajmo opet malo, gospodine župniče!“

$74 \quad$ "Zgodna prilika", Zvekan: humoristični list (1890), br. 2: 18. "Krčmarica: Mužu dodji gore, strašno se lemaju i devetaju. Poubijati će se još. Krčmar: Nisam li ti već jučer kazao, da je naše vino još uviek prejako. Odmah moram prilijati nešto vode."

75 "Promijena vremena po Falbu", Zvekan: humoristički list (1900), br. 13: 102.

76 Aleš, Friedl, "What Do Jokes on Alcoholics Tell us about Alcoholism", Alcoholism: Journal on Alcoholism \& Related Addictions 48 (2012), br. 1: 19.

77 Tipizirana razglednica "Noćni život u Bjelovaru", poštanski upotrijebljena, privatna zbirka Bogavčić.

78 Tipizirana razglednica "Pozdrav iz Zagreba", poštanski upotrijebljena, privatna zbirka Bogavčić. 
bijeloga! (Slika 3). ${ }^{79}$ Sve navedene razglednice prikazuju alkoholizam i konzumiranje alkohola kao općeprihvaćen motiv u prezentiranju vizura mjesta. Slična se stereotipna razmišljanja mogu vidjeti i u karikaturama tiskanima na razglednicama povodom antialkoholnoga kongresa (Slika 4) ${ }^{80}$ Navedene razglednice prikazuju stereotipe o ljudima koji piju alkoholna pića i antialkoholičarima. Ljudi koji konzumiraju alkoholna pića predočeni su kao sretni, socijalno aktivni, korpulentni hedonisti koji uživaju u mesu i piću, dok su antialkoholičari prikazani kao mršavi, usamljeni ljudi kojima na glavi raste povrće jer nisu hedonisti u hrani i piću.

Društvene predrasude o alkoholnim pićima i alkoholiziranome stanju u publikacijama mogu se kategorizirati na one koje su se ticale kvalitete alkoholnih pića prema proizvodnji i na one vezane za moć i djelotvornost alkoholnih pića. Tako se u Domu $i$ svijetu ${ }^{81}$ iz 1892. godine govori o razlici u žestokim pićima iako sva pića loše utječu na ljudsko zdravlje, a kao najveći problem ističu se nečista pića, to jest ona koja imaju u sebi takozvani "nečisti alkohol." (Na primjer konjak, koji ima najmanje nečistoga alkohola, poželjan je za piće.) S druge pak strane, govor zastupnika u Saboru 1914. godine ilustrira stereotipe s kojima se društvo susretalo pa se iz izlaganja zastupnika Dragutina pl. Hrvoja uviđa kako se smatralo da je glavni problem s alkoholizmom u konzumaciji umjetno stvorenoga alkohola, koji je lošiji od prirodnoga alkohola. ${ }^{82}$

Stereotipi u društvu o učinkovitosti alkohola zbog njegovih opijatskih svojstava toliko su bili maštoviti da su se alkoholu pripisivale različite moći te je on imao i utilitarističku funkciju ${ }^{83}$ pa se smatralo da alkohol grije, ${ }^{84}$ jača organizam, ${ }^{85}$ alkohol krijepi dušu i liječi tijelo ${ }^{86}$ te da alkohol hrani. Stereotip da alkohol jača tijelo proizašao je iz ideje povezanosti rada i alkohola, točnije da, kada čovjek konzumira alkohol, može više i bolje fizički raditi. Ideja da alkohol grije proizašla je iz osjećaja topline koju

79 Tipizirana razglednica "Pozdrav iz Zagreba", poštanski upotrijebljena, privatna zbirka Bogavčić.

80 “Anti-alkohol Congress 1901.” Razglednica, privatna zbirka Bogavčić.

81 "Kako djeluju na zdravlje razna žestoka pića”, Dom i sviet: ilustrovani list za zabavu, pouku i viesti o dnevnih dogadjajih, javnom $i$ družtvenom životu, umjetnosti i znanosti, trgovini i obrtu, glasbi, kazalištu i modi (1892), br. 1: 19.

82 "Narodni zastupnik o alkoholu”, Novi život: glasilo Društva apstinenata u Hrvatskoj i Slavoniji (1914), br. 1: 26. Zastupnik Dragutin pl. Hrvoj na sjednici 2. 1. 1914. govorio je o važnosti pijenja i pečenja rakije za stanovništvo. Dragutin pl. Hrvoj kaže da je stanovništvo Slavonije oduvijek pilo rakiju i peklo, samo što je to prije bila domaća rakija, a ne kupovna, takozvana đikan, nego samo šljivovica. I stvar je u tome da u domaćoj rakiji ima svega pa zato mladi obolijevaju. Andrija Štampar zagovarao je mišljenje da alkohol ne može nastati prirodnim putem jer je kemijski spoj. Danas suvremena kemija radi razliku između prirodne fermentacije i proizvodnje alkohola industrijskim putem.

83 Robert Freed Bales, "Cultural differences in rates of alcoholism", Quarterly Journal of Studies on Alcohol 6 (1946), br. 4: 480-499.

84 Ivan Kiseljak, "O alkoholizmu”, Novi naraštaj, list za suzbijanje opojnih pića, za školu i dom 6 (1912): 85. Zbog alkohola nastaje vazodilatacija, čime organizam gubi više topline, što posljedično uzrokuje hlađenje, a ne zagrijavanje tijela.

85 Ivan Kiseljak, “O alkoholizmu”, Novi naraštaj, list za suzbijanje opojnih pića, za školu i dom 7 (1912): 8, 9, 103.

86 Miroslav Čaklović, Najveći neprijatelj čovječanstva alkohol! (Zagreb, Tiskara Hrv. katol. tiskovnog društva, 1908), 12-18. 
alkoholna pića stvaraju u organizmu. Ideje o okrjepi alkoholnim pićima proizašla je iz opojnih svojstava zahvaljujući kojima se ljudi lakše nose s problemima, a opojna svojstva alkohola bila su i izvor umjetničkih i stvaralačkih inspiracija. Ideja da alkohol hrani proizašla je iz prehrambene vrijednosti, na primjer piva, koje je kaloričnije od vina i žestokih pića. Ideja da alkohol liječi najstariji je stereotip koji se temelji na upotrebi alkohola kao lijeka. Alkoholna su pića tijekom prošlosti upotrebljavana kao antiseptik, a budući da alkohol opušta živčani sustav, opušta time i probavni trakt pa djeluje i na bolju apsorpciju hrane, kao što su postojale i ideje da "jača krv". ${ }^{7}$ Zahvaljujući modernoj medicini i znanosti navedene su zablude pojašnjene te je već tada uočeno na koje organe u tijelu alkohol djeluje razorno, u kojoj je mjeri on uzrok psihičkih i fizičkih bolesti te smrtnosti. ${ }^{88}$ Suvremena medicinska, antropološka i sociološka istraživanja podrazumijevaju povremeno uživanje u alkoholu kao socijalno relaksirajuću aktivnost koja je usko vezana uz uživanje $u$ jelu, a ako je u granicama prihvatljivih količina, može imati i profilaktičku zdravstvenu ulogu. ${ }^{89}$

U Trojednoj Kraljevini intelektualne elite poput liječnika ignorirale su neko vrijeme sâmo postojanje protualkoholnoga pokreta i apstinencijskih časopisa. ${ }^{90}$

U nizu edukativnih publikacija ili novinskih tekstova Gudrum Oriovčanin, Štampar, kao i neki drugi autori ${ }^{91}$ govore o vjerovanjima koja su se uvriježila u narodu, a koja nisu imala podrijetlo u tradiciji nego u pogrešnim tumačenjima. Tako u knjizi Mane hrvatskog naroda ili Hrvatsko ogledalo ${ }^{92} \mathrm{u}$ V. glavi ${ }^{93}$ autor objašnjava kako je nastala poslovica Tko pije, taj dođe u nebo. ${ }^{94}$ Pogrešnim zaključivanjem temeljenim na narodnoj pjesmi autor članka navodi zašto su pijanstvo i alkoholizam u narodu pogrešno prihvaćeni kao pozitivna stanja.

87 Dwight B. Heath, International Handbook on Alcohol and Culture (Westport; London: Greenwood Press, 1995), 353, 342. Zbog antiseptičnih, antioksidativnih i preventivnih svojstava povremeno uživanje u alkoholu suvremena znanost smatra korisnim. Tako alkohol snižava razine kolesterola, snižava stvaranje krvnih ugrušaka, potiče cirkulaciju i podiže razinu estrogena. Redovito konzumiranje alkohola u većim količinama smatra se nepoželjnim te takva ponašanja povećavaju mogućnost razvoja bolesti.

88 Ivan Kiseljak, "Pokret proti alkoholu nekoć i danas", Novi život: glasilo Društva apstinenata u Hrvatskoj i Slavoniji 9 (1913): 130.

89 Heath, International Handbook on Alcohol and Culture, 352-355. Mjera od jedne do dvije čaše crnoga vina dnevno smatra se prihvatljivim oblikom konzumacije alkohola.

90 Andrija Štampar, "Liječnici i alkoholno pitanje”, Novi život: glasilo Društva apstinenata u Hrvatskoj i Slavoniji 10 (1913): 147.

91 Dr. Eduardo Spitzer, "Upliv alkoholizma na život ljudski”, Narodne novine (Zagreb), 5.-6. 3. $1891 ., 1$.

92 Josip Dobroslav Božić, Mane hrvatskog naroda ili Hrvatsko ogledalo (Senj, Tiskara Hreljanović, 1906).

93 Trivun Lazić, “Tko pije taj dodje u nebo”, u: Mane hrvatskog naroda ili Hrvatsko ogledalo, 28.

94 Lazić, “Tko pije taj dodje u nebo".

"Tko pije taj je vesel,

Tko je vesel taj pjeva

Tko pjeva zlo ne misli

Tko zlo ne misli, dodje u nebo.

Dakle: Tko pije, dodje u nebo!" 
Učitelji diljem Kraljevina pisali su u Novome životu o razlozima alkoholizma ukazujući na njegovu hedonističku funkciju. ${ }^{95}$ Učitelj iz Požeške županije ${ }^{96}$ naveo je kako “(...) kad u mom kraju seljaka pozoveš na rad, ne će ti se odazvati niti uz najbolju hranu, ako mu nisi dao špire. Za špiru on će i najteži rad obaviti s najvećim veseljem i pregaranjem."

Stanovništvo na selu diljem Slavonije okupljalo se radi svetkovanja, ali i radi obavljanja zajedničkoga posla. Okupljanja, povezana uz rad, odnosila su se na posijela, ${ }^{97}$ spreže ${ }^{98}$ kosidbe $^{99}$ i sličan rad u polju. Tijekom tih poslova stanovništvo je (više nego obično) konzumiralo alkohol. U Glasniku županije Požeške postoji niz članaka pod nazivom "Zašto nam gospodarstvo ne napreduje"100 i sličnih protiv pijanstva, o alkoholizmu i slično u kojima se navodi kako je u Požeškoj županiji alkoholizam bio česta pojava te da se čak u nekoj zadruzi tijekom zime popilo osamdeset akova ${ }^{101}$ vina i dvadeset akova rakije. Budući da je zima bila razdoblje tijekom kojega je opseg posla bio manji, zasigurno se tijekom ostalih godišnjih doba, kada je bilo više radova u polju kao i svetkovina vezanih za slavljenje obavljena posla, pilo više alkohola. U Glasniku županije Požeške navodi se odgovor na pitanje zašto seljak zna često piti: “da je pozajmio nešto novaca, da kupi živeža, pa je da jednom na jade svoje zaboravi, malo više gucnuo." ${ }^{102}$ Kako bi zaboravio na dug koji već ima, seljak se opet zaduživao, samo ovaj put kod krčmara. Seljaci su obično krčmaru plaćali u žitu, a ne u novcu jer novca nisu imali s obzirom da su nakon žetve plodine koje su prodavali bile jeftine, zbog čega su ih vrlo brzo rasprodali sa svrhom namirenja duga. U takvoj situaciji seljaku nije ostalo ništa za život te se morao ponovno zaduživati. Koliko je seljak zaista znao popiti čistoga etanola, opisuje autor članak "Proti pijanstva" ${ }^{103}$ koji govori da bi seljak, ako nije imao šljivovice, otišao u trgovinu ili u gostionicu i naručio četvrtinu ili polovicu litre čistoga etanola te ga miješao s vodom.

\footnotetext{
95 Štifanić, “Alkoholizam i društvene znanosti”, 705.

96 Jure Cindrić, “Učitelji u borbi protiv alkohola”, Novi život: glasilo Društva apstinenata u Hrvatskoj i Slavoniji 4 (1913): 58-61.

97 Hrvatska (dalje: HR) - Državni arhiv u Slavonskom Brodu (dalje: DASB) - Odjel Nova Gradiška (dalje: ONG), Fond Školske spomenice (dalje: FŠS) - Školska spomenica Seoce, inv. br. 99. Posijela su bila okupljanja žena radi izrade odjeće. Ona su se sve rjeđe događala jer su žene sve češće kupovale tanak pamuk koji nisu htjele više tkati od grube konoplje ili lana.

98 HR-DASB-ONG-FŠS-Školska spomenica Seoce, inv. br. 99. Spreža je bila ugovor između dviju zadruga oko rada na zajedničkome poslu.

99 HR-DASB-ONG-FŠS-Školska spomenica Seoce, inv. br. 99. Kosidba je bio običaj košenja koji se tijekom razdoblja zadružna života svetkovao u velikome slavlju, a običaj je nestao nakon raspada zadruga.

100 Š. V. y.: “Zašto nam gospodarstvo ne napreduje”, Glasnik županije Požeške (Požega), 23. 1. 1892. 12. 3. 1892.

101 Akov je stara mjera za tekućine i iznosi 56,6 litara. "Akov", Hrvatski leksikon, pristup ostvaren 1.3.2015. http://www.hrleksikon.info/definicija/akov.html.

102 J. Bobinac, "Rane u seljačkom staležu”, Glasnik županije požeške (Požega), 8. 11. 1902., 1.

103 "Proti pijanstvu”, Glasnik županije Požeške (Požega), 18. 3. 1893., 1.
} 
Pokušaju li se saznati uzroci alkoholizma, zanimljiv primjer daje Dušan Marković, kotarski veterinar iz Slunja, ${ }^{104}$ koji kao o uzroku alkoholizma govori o neobrazovanosti, neplodnoj zemlji, točnije siromaštvu, te iseljavanju. Iseljavanje se povezuje s alkoholizmom u objašnjenju učitelja Dizdara koji, opisujući život u zadarskome zaleđu, govori o tome kako povratnici iz Amerike troše novac na alkohol u krčmama. ${ }^{105}$ Učitelji diljem Slavonije i Like pisali su o postojanju više gostionica nego škola u županijama. Primjer su toga Požeška županija kao i stanje u Imotskome. Sela u Dalmatinskoj zagori imala su po četiri ili pet krčmi i nijednu školu. U samome Imotskom, koje je ima tri tisuće stanovnika, bila je jedna škola i petnaest krčmi. U Požeškoj županiji na deset krčmi postojale su dvije i pol škole. Točnije, 1913. godine bilo je u Požeškoj županiji 230 škola, a 633 krčme. U gradovima Požeške županije odnos je bio takav da je u Brodu jedna krčma bila na 237 stanovnika, u Požegi jedna krčma na 184 stanovnika, u Daruvaru je bila jedna krčma na 203 stanovnika, u Pakracu na 230 stanovnika, a u Novoj Gradiški bila je jedna krčma na 144 stanovnika. ${ }^{106}$

Ta vrsta kulturne ambivalentnosti ${ }^{107}$ oko same uloge alkoholnih pića - gdje su s jedne strane alkoholna pića slavljena, reklamirana i smatrana izvorom čovjekove moći, a s druge strane bila su zdravstveno štetna - vjerojatno je i utjecala na takozvanu zbunjenost običnoga čovjeka koji nije znao kako se odnositi prema tome problemu. Iako je u Trojednoj Kraljevini početkom 20. stoljeća započeo protualkoholni pokret (potaknut pojedincima iz društvenih elita poput učitelja, svećenstva i liječnika), pretjerano uživanje u alkoholnim pićima još uvijek nije prepoznato kao negativno niti ga je država označila kao takvo, što je itekako otežalo bilo kakav rad apstinencijskih društava.

Za razliku od Cislajtanije, gdje se vodio neki oblik statistike o postojanju alkoholičara, u Kraljevinama o problemu alkoholizma i alkoholičara moramo zaključivati posredno na temelju raznovrsnih izvješća. Prema potrošnji alkohola uviđa se kako se 1912. godine u Češkoj za alkohol potrošilo godišnje tristo milijuna kruna, u Moravskoj 118 milijuna, Austriji 1700 milijuna, a u Hrvatskoj sto milijuna kruna. ${ }^{108}$ Posredni pokazatelji potrošnje alkoholnih pića, proizvodnje alkohola, kao i zločina počinjenih u pijanome stanju mogu preliminarno pokazati u kojoj je mjeri alkoholizam bio sveprisutna pojava.

O točnoj količini, to jest potrošnji alkoholnih pića, teško je govoriti iako postoje usporedni pokazatelji koji upućuju na to da su se konzumirale velike količine alkoholnih pića. Prema izvješću Gostioničarske zadruge sa sastanka održanoga 23. rujna 1913. "istočeno je vina 852 hl dok je špirita uvezeno željeznicom 2000 hl, a podvozom

104 Dušan Marković, “Antialkoholni pokret u slunjskom kotaru”, Novi život: glasilo Društva apstinenata u Hrvatskoj i Slavoniji 6 (1913): 87.

105 I. Dizdar, "Zaraza alkohola u dalmatinskom zagorju”, Novi život: glasilo Društva apstinenata u Hrvatskoj i Slavoniji 4 (1914): 58.

106 "Škola i učitelji u borbi proti alkoholu”, Novi život: glasilo Društva apstinenata u Hrvatskoj $i$ Slavoniji 2 (1914): 30.

107 Štifanić, "Alkoholizam i društvene znanosti”, 707.

108 “Žalosni brojevi”, Novi život: glasilo Društva apstinenata u Hrvatskoj i Slavoniji 2 (1913): 31. 
kolnim iz pecare žeste iz Cernika cio njezin kontingent od 720 hl, svega 3328 hl $^{109}$ špirita." 110 Izvezena je trećina toga etanola izvan novogradiškoga kotara, a ostalih 2000 hl ostalo je za potrošnju u općini. Od tih 2000 hl etanola rađena je šljivovica u omjeru 1/5 etanola i 4/5 vode pa je na taj način u općini Nova Gradiška potrošeno deset tisuća hektolitara šljivovice. ${ }^{111}$ Trgovište, to jest općina Nova Gradiška imala je 1910. godine 3400 stanovnika $^{112}$ zbog čega se postavlja pitanje koliko je zaista litara šljivovice odrasli stanovnik trgovišta popio u jednoj godini. Ako bi bila riječ samo o stanovnicima trgovišta, onda bi iz toga proizlazilo da je svaka osoba godišnje popila oko tristo litara šljivovice, ali - budući da je tu riječ i o velikome broju gostiju u brojnim gostionicama i krčmama - nemoguće je precizno reći koliko su stanovnici samoga trgovišta godišnje pili šljivovice.

Prema podatcima koje donosi Andrija Štampar, u općini Nova Gradiška ${ }^{113}$ godine 1912. potrošeno je na alkoholna pića pola milijuna kruna, što je izračunato prema potrošarinama na alkohol, državnome porezu na alkohol i općinskome nametu na alkohol. ${ }^{114}$ Prema njegovoj računici u općini Nova Gradiška godišnje je popijeno 514 416 litara vina, što iznosi 143,9 litara po osobi. Navedeno je samo u domeni vina, koje čak nije bilo ni glavno alkoholno piće koje se konzumiralo u kotaru Nova Gradiška. Stanovništvo Karlovca je, prema računici Andrije Štampara, tijekom 1913. godine prema plaćenome porezu, tj. raznim trošarinama, konzumiralo 2062500 litara vina $^{115}$ što iznosi 121,3 litre po osobi. Ako na razini kotarâ usporedimo podatke koji postoje o kotaru Slunj i o kotaru Imotski za 1912. godinu, onda se vidi da se u kotaru Slunj godišnje popilo alkohola za 900.000, a u kotaru Imotski za 2.250 .000 kruna. ${ }^{116} \mathrm{~S}$

109 “Proti pijanstvu”, Glasnik županije Požeške (Požega), 18. 3. 189., 1. Zbroj naveden u Glasniku županije Požeške ne odgovara računici te bi, prema navedenome, trebao biti manji, ali - budući da ostaje nepoznato koliki je bio udio etanola u vinu, to jest je li taj udio bio $12 \%$ ili neki drugi nepoznato ostaje koliko je zaista bilo hl špirita.

110 "Proti pijanstvu”, Glasnik županije Požeške, (Požega), 4. 10. 1913., 1.

111 Salopek Bogavčić, Novogradiški kotar, 197.

112 Salopek Bogavčić, Novogradiški kotar, 197.

113 Andrija Štampar ne navodi odakle su preuzeti podatci. U trgovištu Nova Gradiška godine 1910. živjela su 3574 stanovnika. Upravna općina Nova Gradiška sastojala se samo od trgovišta Nova Gradiška.

114 "Koliko trošimo za alkohol”, Novi život: glasilo Društva apstinenata u Hrvatskoj i Slavoniji 10 (1913): 157.

115 “Koliko trošimo za alkohol”, Novi život: glasilo Društva apstinenata u Hrvatskoj i Slavoniji 9 (1913): 143. U prihodu grada Karlovca od državne i općinske potrošarine za žestoka pića iskazano je za 1913. godinu 330.000 kruna. Državni je porez predviđen za 157.000 kruna, a općinski 35.000 kruna. U Karlovcu je 1910. godine bilo 16992 stanovnika.

Računica pokazuje da, ako se sav alkohol koji je popijen u gradu Karlovcu pretvori u vino, od jedne litre vina u Karlovcu plaća se šest filira državne, šest filira općinske, četiri filira uvoznine, tj. ukupno šesnaest filira potrošarine. U Karlovcu se godišnje popije 2062500 litara vina, a ako je jedna litra po jednu krunu, onda se potroši 2.062.500 kruna.

116 I. Dizdar, “Zaraza alkohola u dalmatinskom Zagorju”, Novi život: glasilo Društva apstinenata u Hrvatskoj i Slavoniji 1 (1914): 59. Služeni podatci za kotar Imotski za 1912. godinu: 20000 hl vina, 2400 hl piva, ukupno, prema Dizdarovu navođenju, 2 1⁄4 milijuna litara pića. Ako je jedna litra alkohola jedna kruna, onda se potrošilo 2.250.000 kruna godišnje, što je na 42000 stanovnika iznosilo $49 \mathrm{k}$. po osobi. 
druge pak strane, odvjetnik Josip Godler iz Siska navodi kako tvornica žeste u Topolovcu kod Siska može proizvesti godišnje 1400 hl žeste, a da se vjerojatno u samome kotaru potroši 5000 hl žeste godišnje. Nadalje odvjetnik navodi kako se vjerojatno popije $15000 \mathrm{hl}$ alkoholnih pića ${ }^{117}$ na 25000 stanovnika. ${ }^{118}$ Prema toj računici potroši se šezdeset litara žeste po stanovniku godišnje, a ako se ona razrijedi, onda se po stanovniku dobije 180 litara rakije.

O povezanosti zločina i alkoholizma pisao je Milan Kostić. ${ }^{119}$ Radeći na testnoj skupini zatvorenika kaznionice Mitrovica, naglasio je kako alkoholizam nije individualna stvar nego višedimenzionalan problem u društvu. Iz te premise zaključuje o povezanosti alkoholizma s drugim aspektima života stavljajući posebice naglasak na odnos kriminaliteta i alkoholizma. U nekoliko tablica donosi statistički pregled povezanosti vrsta zločina s alkoholom, ${ }^{120}$ povezanosti alkoholizma i zemljopisnoga područja ${ }^{121}$ te alkoholizma i ekonomske situacije. ${ }^{122}$ Prema Kostićevoj statistici u Kraljevini Hrvatskoj i Slavoniji najviše se pilo vina, rakije pa tek onda piva, a tijekom razdoblja od 1908. do 1911. godine smanjeni su prihodi od vinogradarske produkcije zbog sve lošijega uroda pa se time smanjila i potrošnja vina i rakije, što je rezultiralo povećanom konzumacijom piva. Tijekom razdoblja od 1908. do 1911. godine više je zločina počinjeno u alkoholiziranome nego u trijeznome stanju. Ta je razlika najočitije bila vidljiva 1908. godine, a najmanja je razlika uočena 1911. godine. ${ }^{123}$ Smanjenje udjela osoba koje su činile zločine u alkoholiziranome stanju od 1908. do 1911. godine povezano je s urodom vrsta od kojih se dobivao alkohol. ${ }^{124}$ Budući da je 1908. bila izrazito rodna godina i za šljivu i za grožđe, te je godine bilo i najviše zločina počinjenih u alkoholiziranome stanju, dok je 1910. bila izrazito nerodna pa je moguće uočiti kako je ekološko-ekonomska situacija utjecala na socijalni problem. Kostić je utvrdio da postoji uvjetovanost između teških vrsta zločina (poput ubojstva, ranjavanja i silovanja) i alkoholizma jer su takve vrste zločina češće kada je vinogradarski prirod bolji, dok su s druge strane teži ekonomski uvjeti uvjetovali povećanje drugih oblika zločina poput krađe, koji su počinjeni u trijeznome stanju.

Prema Kostićevim statističkim podatcima čak 72,78 \% ubojica bilo je pri izvršenju zločina pod utjecajem alkohola. Najmanja razlika između alkoholiziranih i trijeznih

117 Josip Godler, "Naša narodna smrt”, Novi život: glasilo Društva apstinenata u Hrvatskoj i Slavoniji 5 (1914): 67. Riječ je o vinu, rakiji, pivu i žesti. Od jedne litre žeste nastanu tri litre rakije.

118 Josip Godler, "Naša narodna smrt”, Novi život: glasilo Društva apstinenata u Hrvatskoj i Slavoniji 5 (1914): 67. Budući da nije riječ o statističkim podatcima, nego o informativnome tekstu autora, podatci su navedeni kao ilustrativni primjer.

119 Milan Kostić, Alkohol, kriminalitet i pravo (Zagreb: Dionička tiskara, 1912).

120 Kostić, Alkohol, kriminalitet i pravo, 20. Tablica C: Alkohol i zločin.

121 Kostić, Alkohol, kriminalitet i pravo, 30.

122 Kostić, Alkohol, kriminalitet i pravo, 32.

123 Od ukupnoga broja kažnjenika kaznionice Mitrovica u 1908. godini njih 60,76 \% počinilo je zločin u pijanome stanju, a 1911. godine taj se udio smanjio na 51,62 \%.

124 Kostić, Alkohol, kriminalitet i pravo, 19. 
osoba bila je u domeni javnoga nasilja. ${ }^{125}$ Prema zemljopisnoj rasprostranjenosti alkoholnih pića među zatvorenicima mitrovačke kaznionice najviše se vina pilo u mitrovačkome i osječkome kraju, a rakije u požeškome kraju. ${ }^{126} \mathrm{Na}$ osnovi podataka koje je sakupio Milan Kostić, više se zločina pod utjecajem alkohola događa u hladnijim područjima i to vikendom i praznikom. Objašnjenje za to jest u činjenici da se ljudi tada više opuštaju i provode vrijeme zajedno uz alkohol. Također su zanimljiva opažanja o povezanosti alkoholizma s kriminalom i godišnjim dobima pa tako Kostić smatra da se više zločina događa tijekom jeseni kada se peče rakija i beru vinogradi. Specifična je i povezanost mjesta zločina sa socijalno-ekonomskim statusom pa Kostić navodi kako su češći zločini na ulici i u blizini krčme nego na primjer u polju ${ }^{127}$ iako se alkoholizam češće pojavljuje u poljoprivrednika, nadničara i tvorničkih radnika nego kod drugih zanimanja. ${ }^{128}$ Kostićeva statistika bila je dio moderne statistike koja je tada započela pratiti učinak alkohola na društvo u raznim segmentima od prava, zdravstva, gospodarstva i slično, što je sve ukazivalo na to kakav je alkoholizam zaista problem u društvu. Iako alkoholizam može biti uzrok devijantnoga ponašanja te je često bio povezan s njime, tadašnji europski protualkoholni pokret nije smatrao alkoholičara a priori kriminalcem; takav stav proizlazio je često iz vjerski organizirane borbe protiv alkohola, dok su liječnici alkoholičarima pristupali kao bolesnicima koje je trebalo liječiti129 i rehabilitirati u za to posebnim lječilištima. ${ }^{130}$ U Trojednoj Kraljevini takvih lječilišta nije bilo, ali su u kaznenome zatvoru Mitrovica postajali neki vidovi edukacije o štetnosti alkoholizma. ${ }^{131}$

Svi navedeni čimbenici - od običaja, tradicije, stereotipa, neadekvatnoga obrazovanja, iseljavanja pa do siromaštva i rasprostranjenosti kultura vinove loze ili šljive - utjecali su na porast alkoholizma, što se nije moglo pratiti izravnim statističkim pokazateljima, ali posrednim pokazateljima uvidjelo se kako je alkoholizam postajao sve veći problem.

125 Kostić, Alkohol, kriminalitet i pravo, 19. Tijekom razdoblja od 1908. do 1911. godine od svih kažnjenika bilo je 58,14 \% pijanih i 41,86 \% trijeznih.

126 Kostić, Alkohol, kriminalitet i pravo, 32.

127 Kostić, Alkohol, kriminalitet i pravo, 52.

128 Kostić, Alkohol, kriminalitet i pravo, 64.

129 Studen, Pijane zverine, 44. Već Franz Wilhelm Lippich, ljubljanski liječnik s početka 19. stoljeća, govori o lječilištima za alkoholičare.

130 Dragan Drganc, "Lječilišta za alkoholičare”, Novi život: glasilo Društva apstinenata u Hrvatskoj i Slavoniji 6 (1913): 83; 7 (1913): 98-103. Lječilišta za alkoholičare otvarana su u Njemačkoj i Švicarskoj kao privatne ustanove gdje su pojedinci dolazili svojom voljom.

131 Milan Kostić, "Suzbijanje alkoholizma u mitrovačkom kaznenom zatvoru”, Novi život: glasilo Društva apstinenata u Hrvatskoj i Slavoniji 8 (1913): 121. 


\section{Pojava apstinencijskih pokreta: Fran Gudrum Oriovačnin, Nikola Đurić i Andrija Štampar}

Tijekom prošlosti prvi su alkoholi, ${ }^{132}$ to jest alkoholna pića nastali procesom prirodnoga vrenja, a od 19. stoljeća alkohol nastaje kao rezultat industrijske proizvodnje. Pri procesu prirodnoga vrenja narodi su se za dobivanje alkoholnih pića koristili šećerom dobivenim iz voća ili žitarica poput šljive, grožđa, ječma, hmelja, riže, šećerne trske ili agave, a u suvremeno se doba alkohol dobivao i iz šećera prisutnih u kukuruzu, brašnu, krumpiru i slično, što je utjecalo na jeftiniju i veću proizvodnju alkoholnih pića. Tijekom prapovijesti čovjek je od fermentiranoga meda proizvodio alkohol, a pretpostavka je kako je sam proces destilacije potekao iz arapskoga svijeta te je u 11 . stoljeću korišten u medicinskoj školi u Salernu. ${ }^{133}$ Alkohol je od 14. stoljeća poistovjećivan s lijekom i čudom za očuvanje mladosti te je nazivan aqua vitae. Oživljavao je srce, liječio kolike, mišićne tenzije, zubobolju te je bio i preventiva protiv kuge. ${ }^{134} \mathrm{Ti}$ jekom prošlosti smatralo se da se inspiracija i polet mogu pronaći u alkoholu. Budući da je sve masovnijom industrijskom proizvodnjom alkohol postao dostupan i jeftin, konzumacija je olakšana, a alkoholna su pića postala socijalno prihvatljiva i raširena u svim društvenim grupacijama.

Alkoholizam kao pojam pojavljuje se tek u 19. stoljeću kao bolest pod nazivom alcobolismus. ${ }^{135}$ Potkraj 18. stoljeća pojavljuju se religiozni pokreti protiv alkohola, koje su u Velikoj Britaniji vodili kvekeri i metodisti. Na kraju istoga stoljeća u SAD-u je dr. Leslie Kelly osnovao Ligu za borbu protiv alkoholizma, kojom je započeo i rad na antialkoholizmu. Početkom 19. stoljeća Englez Thomas Trotter i Amerikanac Benjamin Rush ${ }^{136}$ prvi su 1813. godine pisali o alkoholizmu kao bolesti te su prepoznali da dugotrajna konzumacija alkohola rezultira ovisnošću, propašću jetre i mentalnom disfunkcijom. ${ }^{137}$ U SAD-u se borba protiv alkoholnih pića intenzivirala oko 1826. godine razvojem društava koja su težila umjerenosti u alkoholu.

132 Alkohol kao organski spoj nastaje tijekom kemijskoga procesa, tj. vrenja ili fermentacije. Zahvaljujući procesu fermentacije šećer se pomoću enzima (najčešće kvasca) pretvara u etanol i $\mathrm{CO}_{2}$. Etanol ili etilni alkohol tijekom prošlosti nazivan je spirus tj. "špiritom” ili prirodnim alkoholom.

133 Tim Unwin, Wine and the Vine: An Historical Geography of Viticulture and the Wine Trade (London; New York: Routledge, 1991), 235.

134 Braudel, Civilization and Capitalism 15 $15^{\text {th }}-18^{\text {th }}$ Century, 242.

135 Hudolin, Alkohološki priručnik, 4. Službeno je Magnus Huss godine 1849. uveo termin “kronični alkoholizam" te je za to djelovanje bio i nagrađen 1853. godine. Opisivao je komplikacije alkoholizma, a ne vezu alkohola i osobe. Franz Wilhelm Lippich još nije dovoljno rasvijetljen te se ne zna opseg i značenje njegovoga pionirskog djelovanja početkom 19. stoljeća.

136 Vinko Matijević, “O policiji ćudorednosti u opće, a napose o zadatcih uprave proti alkoholizmu s osobitim obzirom na naše domaće odnošaje”, Radnički Glasnik: list za interese hrv. radničkog staleža (Zagreb), 15. 6. 1888., 1. Benjamin Rush već je 1804. godine upozorio na štetnost alkoholnih pića, a 1808. godine osnovao je prvo Društvo umjerenih korisnika alkoholnih pića u Morei, SAD.

137 Marica Jandrić-Balen, Ivica Balen, “Andrija Štampar i borba protiv alkoholizma”, u: Andrija Štampar. Knjiga I.: Mladost Andrije Štampara (1888.-1919.), prir. Ivica Balen i Stana Vukovac (Osijek; Slavonski Brod: Sveučilište Josipa Jurja Strossmayera u Osijeku; Opća bolnica “Dr. Josip Benčević” Slavonski Brod, 2006), 85-86. 
Prvi protualkoholni pokreti težili su više umjerenosti u piću nego apstinenciji. U Engleskoj su takva društva nastala pod utjecajem Katoličke Crkve u 19. stoljeću. Pokret umjerenosti pojavio se oko 1829. godine u Engleskoj, oko 1850. u skandinavskim zemljama poput Danske i Švedske, a od 1838. godine pokret je počeo djelovati i u Njemačkoj. ${ }^{138}$ Prema Ernestu Gordonu ${ }^{139}$ protualkoholičarski pokreti počeli su djelovati u Njemačkoj oko 1895. godine kada je izdana Deklaracija o apstinenciji od alkohola u medicinskoj struci. U Njemačkoj su počela s radom i društva protualkoholičara, koja su potaknule razne struke na udruživanje pa su tako učitelji i svećenici imali svoja društva i glasila koja su se razlikovala od društava i glasila liječnika, trgovaca ili radnika. Skandinavske zemlje prve su poradile na legislativi o zabrani alkoholnih pića.

Djelovanje na suzbijanju alkoholizma prepoznato je i u široj regiji. Tako je na području Kraljevine Srbije već 1906. godine postojalo Protualkoholičarsko društvo za suzbijanje alkoholnih pića u Beogradu, koje je redovito organiziralo regionalne skupštine. ${ }^{140}$ U Bosni i Hercegovini ${ }^{141}$ godine 1906. započelo je s radom Islamsko društvo protualkoholičara u Rogatici i Brčkom, potom Društvo protualkoholičara Srba u Foči i Višegradu te u Sarajevu. ${ }^{142}$

Na državnoj razini Austro-Ugarske Monarhije prvo se pojavilo glasilo Der Abstinent (Apstinent), koje je uređivao dr. Karl Freund, ${ }^{143}$ što je označavalo početak ozbiljnijega znanstvenog, a ne samo moralnoga, protualkoholnog djelovanja. U zemljama Ugarske Krune rad Društva protualkoholičara organizirala je Velika loža dobrih hramovnika, koja je izdavala glasilo Az Alkoholkérdés ("Alkoholno pitanje”). ${ }^{144}$ Tijekom 1885. godine organiziran je u Beču i prvi Međunarodni protualkoholičarski kongres, drugi je organiziran u Grazu, treći u Salzburgu, a četvrti u Brnu. ${ }^{145}$ Paralelno su se javljali i civilni oblici djelovanja na suzbijanju alkoholizma: od težnji za organiziranjem gostionica bez alkohola, ${ }^{146}$ izrade vina bez alkohola, ${ }^{147}$ poticanja uloge žene u borbi protiv alkoholizma do organiziranja raznih predavanja o alkoholizmu pa čak i azila za pijan-

138 “The Temperance Movement”, pristup ostvaren 14. 11. 2015., https://www.u-s-history.com/pages/h1054.html.

139 Ernest B. Gordon, Anti-Alcohol Movement in Europe (New York: Fleming H. Revell Company, 1913), 11-12.

140 Salopek Bogavčić, Novogradiški kotar, 322.

${ }_{141}$ "Mjere proti pijanstvu", Narodne novine (Zagreb) 1. 10. 1888., 1. Izdane su Mjere protiv pijanstva u Bosni i Hercegovini zbog povećanoga broja alkoholičara u zadnja dva desetljeća.

142 Salopek Bogavčić, Novogradiški kotar, 322.

143 Nikola Đurić, "Vijesti”, Novi naraštaj, list za suzbijanje opojnih pića, za školu i dom 1 (1906): 78-80.

144 Nikola Đurić, "Rad na suzbijanju pijanstva”, Novi naraštaj, list za suzbijanje opojnih pića, za školu idom 1 (1912): 8.

145 Gordon, Anti-Alcohol, 83.

146 G[ospođa] Jelica, "Rad na suzbijanju alkoholnih pića”, Novi naraštaj, list za suzbijanje opojnih pića, za školu i dom 2 (1906): 30. Jedna takva gostionica otvorena je u Beču, a organiziralo ju je Društvo apstinentkinja Bečanki.

147 Nikola Đurić, “Antialkoholna pića”, Novi naraštaj, list za suzbijanje opojnih pića, za školu $i$ dom 4 (1906): 49. Takvo vino bez alkohola na vinarskoj izložbi 1905. godine u Požegi izložilo je Kutjevačko vlastelinstvo. 
ce. ${ }^{148}$ Sav taj rad u početcima je bio organiziran kao amaterizam koji je poprimio oblik pokreta, a poslije i organiziranoga djelovanja. Službeni su se poticaji počeli uočavati prvo u ugarskome dijelu Krune kada je Ministarstvo prosvjete prepoznalo važnost borbe protiv alkoholizma te je 1907. godine tražilo da se u svaki udžbenik uvede poglavlje o štetnosti alkohola. Ugarsko Ministarstvo prosvjete također je od 1912. uvelo jedan dan u nastavi koji je bio posvećen educiranju djece o štetnosti alkohola. ${ }^{149}$

U Kraljevini Hrvatskoj i Slavoniji postojalo je nekoliko apstinentskih pokreta i sporadičnih okupljanja entuzijasta prije no što je došlo do osnivanja društva protualkoholičara. Liječnik Fran Gudrum Oriovčanin ${ }^{150}$ započeo je s protualkoholnim djelovanjem 1904. godine tiskanjem publikacije Alkohol-otrov te potom 1905. Alkohol i djeca i 1906. Apstinencija. Fran Gudrum Oriovčanin bio je (1882. - 1888.) gradski liječnik u Brodu na Savi. ${ }^{151}$ Doktor Oriovčanin preselio se u Križevce gdje je nastavio svoj rad u domeni socijalnoga zdravstva pa se tako bavio i protualkoholnom izdavačkom djelatnosti. Spoznaje do kojih je došao radom u Slavoniji bile su slične onima do kojih je došao učitelj Nikola Đurić152 u Cagama, kotar Nova Gradiška. Obojica su uvidjela u kolikoj mjeri uživanje alkohola šteti zdravlju te su pokušali organizirati prva okupljanja istomišljenika liječnika i učitelja oko novotiskanoga časopisa Novi naraštaj, list za suzbijanje opojnih pića, za školu i dom. Časopis je počeo izlaziti 1906. godine u Cagama kod Nove Gradiške kao prvo protualkohološko glasilo. Nikola Đurić, vlasnik i glavni urednik časopisa Novi naraštaj, okupio je oko navedenoga časopisa mnoštvo tadašnjih istaknutih istomišljenika poput Vitasa, dr. Gudruma-Oriovčanina, Mitrovića, Svitlića, Miljkovića, Popovića, Danića, Jovanovića, Veloviđeru, dr. Kiseljaka, dr. Kostića, Milutinovića, Stevu Kutuzova i mlade liječnike poput dr. Štampara, Cihlara i Šašela. ${ }^{153}$ U Pokretu ${ }^{154}$ se pisalo o alkoholizmu kao "najužasnijoj bolesti narodnoj” te kako će list svim dopuštenim sredstvima raditi na suzbijanju alkoholizma.

Časopis Novi naraštaj ${ }^{155}$ preporučila je Zemaljska vlada ${ }^{156}$ 17. kolovoza 1906. Vlasnik i urednik bio je Nikola Đurić, a odgovorni urednik bio je učitelj Lazar Kekić.

148 Vinko Matijević, “O policiji ćudorednosti u opće, a napose o zadatcih uprave proti alkoholizmu s osobitim obzirom na naše domaće odnošaje”, Radnički Glasnik: list za interese hrv. radničkog staleža (Zagreb), 15. 8. 1888., 2. Postojao je prijedlog da se u zgradi prisilne radionice u Weinhausu ustroji azil za alkoholičare.

149 Gordon, Anti-Alcohol, 19.

150 Fran Gudrum Oriovčanin (1856. - 1919.), hrvatski liječnik i književnik. Kao liječnik djelovao je u Brodu, po raznim mjestima u Bugarskoj te na kraju u Križevcima. Bio je zdravstveni prosvjetitelj, promicatelj higijenskoga načina življenja te borac protiv alkoholizma i pušenja. Izdao je nekoliko knjižica o prevenciji zdravlja te je bio predsjednik Društva apstinenata Hrvatske i Slavonije. "Fran Gundrum Oriovčanin”, Hrvatska enciklopedija (on-line), Leksikografski zavod "Miroslav Krleža”, pristup ostvaren 10. 8. 2015. http://www.enciklopedija.hr/natuknica.aspx?id=23789 . Jandrić-Balen, Balen, “Andrija Štampar i borba protiv alkoholizma”, 86.

152 Nikola Đurić, učitelj iz Caga, pokretač časopisa Novi naraštaj.

153 Salopek Bogavčić, "Novogradiški kotar", 323.

154 Pokret, glasilo hrvatskih naprednjaka (Zagreb) 19. 1. 1906., 1.

155 Nikola Đurić, Novi Pogledi, Izdali novogradiški trezvenjaci u korist siromašnih đaka trezvenjaka (Nova Gradiška: M. Mlađan, 1913), 22.

156 Đurić, Novi Pogledi. Trebala ga je posjedovati svaka školska knjižnica. 
Svrha je glasila bila "obavješćivati o napretku apstinencije (...)”157, a želja uredništva bila je suradnja s priznatim stručnjacima i stranim društvima. Glasilo se sastojao od "Podlistka" u kojemu su bili navedeni primjeri iz života alkoholičara, od "Vijesti" u kojima se pratio napredak i djelovanje društva, a zatim "Književnosti” gdje su bile objavljene informacije o izdavačkoj djelatnosti. Osim navedenoga glasilo je donosilo stručne tekstove liječnika o alkoholizmu, potom je pratilo događanja o alkoholizmu $\mathrm{u}$ inozemstvu, a na kraju svakoga broja donosilo je i urednikove poruke. ${ }^{158}$

Nikola Đurić i dr. Gudrum Oriovčanin pokušali su formirati protualkoholičarsko društvo sa sjedištem u Zagrebu tijekom 1906. godine. U časopisu su predočeni nacrti budućega društva kao i pravila društva, ali zbog malenoga broja pretplatnika časopis je nakon prve godine prestao izlaziti. Od dvije tisuće primjeraka koji su poslani fizičkim osobama, školama i raznim institucijama bilo je samo 139 pretplatnika, što je bio premalen broj da bi glasilo opstalo. ${ }^{159}$ Zanimljiva je statistika o korisnicima, koju je objavio Nikola Đurić u samome časopisu: od 139 pretplatnika njih 102 bili su Srbi, a 37 Hrvati. Možda je to i bio razlog zbog kojega je časopis naišao na nešto slabiji odaziv jer je Srpska štamparija Zagreb stajala iza tiskanja časopisa te se on podrazumijevao kao srpsko glasilo. Od tih 139 korisnika 17,9 \% činile su škole, potom 11,5\% trgovci, dok je (npr. medicinski kadar) činio samo $5 \%$ pretplatnika, a gostioničari tek 3,5 \%. Također su izrazito malen udio činile čitaonice 5,7 \%, a 6,4 \% razna društva, dok su učitelji, svećenici i trgovci činili 30,2 \% ukupnoga udjela pretplatnika. ${ }^{160}$ Glasilo Novi naraštaj nije izlazilo od 1906. do 1912. godine, točnije, izišla su ukupno tri godišta: 1906., 1912. i 1913. Takva duga stanka i neformalna djelatnost do 1911. godine utjecale su na sve veći angažman treće osobe koja je postala sinonimom borbe protiv alkoholizma u Kraljevini.

Treća ključna osoba za početak apstinencijskoga procesa u Kraljevini Hrvatskoj i Slavoniji bio je Andrija Štampar, koji je tijekom djetinjstva u Mrazoviću spoznao problem alkoholizma i njegova utjecaja na pojedinca ${ }^{161}$ pa onda i društvo. ${ }^{162}$ Kao student

157 Nikola Đurić, “Urednikove poruke”, Novi naraštaj, list za suzbijanje opojnih pića, za školu i dom 1 (1906): 2 .

158 Nikola Đurić, "Urednikove poruke”, Novi naraštaj, list za suzbijanje opojnih pića, za školu i dom 1 (1906): 2.

159 Nikola Đurić, “Urednikove poruke”, Novi naraštaj, list za suzbijanje opojnih pića, za školu i dom 6 (1906): 92.

160 Nikola Đurić, "Urednikove poruke", Novi naraštaj, list za suzbijanje opojnih pića, za školu i dom 6 (1906): 92. Izračun autorice temeljem podataka u tablici pretplatnika.

161 Dnevnički zapisi Andrije Štampara govore o tome kako je u djetinjstvu uočavao alkoholizam u selu Mrzoviću u Đakovštini. "Gada mu njegovog gospodska, nek zna, šta je Šokac. On se nagne nad prozor i saziva: Odite bosonje i napijte se! (...). Ja sam gazda, niko mi ništa ne može (...). Sutra sve drukčije. Marko osamljen. Gubi imanje, kuću, a ipak u nevjerici protestira s prozora kuće koja već nije njegova: 'Reci im, (...) da će ih prije gazda Marko stjerat s cipela u opanke, nego oni njega s grunta očinskog.' Epilog: Danas kopa grobove i moli po kućama rakiju!” Stana Vukovac, "Zrnje iz života Andrije Štampara Andrija Štampar vizionar i praktičar” (priopćenje na znanstvenom skupu: Štamparova načela i suvremeni zdravstveni izazovi, Škola narodnog zdravlja "Andrija Štampar", Medicinski fakultet Sveučilišta, Zagreb, Hrvatska 3. i 4. 10. 2008.), pristup ostvaren 5. 8. 2015., www.hcjz.hr/index.php/hcjz/article/download/952/911.

162 Jandrić-Balen, Balen, “Andrija Štampar i borba protiv alkoholizma”, 87. 
tijekom školovanja za liječnika u Beču objavio je velik broj radova na temu alkoholizma. Od ukupno oko sedamdeset članaka objavljenih tijekom studija ${ }^{163}$, njih desetak je do 1911. godine bilo vezano za temu alkoholizma, ${ }^{164}$ a tijekom 1912./1913. godine napisao je još pet različitih članaka ${ }^{165}$ o alkoholizmu. Tijekom 1911. godine pokrenuo je izdavanje serije knjiga Knjižnica proti alkoholu o štetnome djelovanju alkohola. Navedena je serija obuhvaćala deset naslova, a Štampar je bio autor dviju knjižica o alkoholu. Riječ je o knjižicama Je li alkohol hrani? i Narodna čitanka o alkoholu. Ostali autori koji su pisali o temi alkoholizma ili čiji su tekstovi o alkoholizmu iskorišteni u sklopu projekta serije knjiga Knjižnica proti alkoholu bili su: Milan Kostić, Tomáš Masaryk, Ivan Kiseljak, Justus Gaule, Fran Gudrum-Oriovčanin i Nikola Đurić. Tijekom 1909./1910. godine Andrija Štampar započeo je hospitaciju u novogradiškoj bolnici pod utjecajem dr. Mladenovića. Tijekom 1911. djelovao je na suzbijanju alkoholizma u okolici Oriovca, tj. u Radovanju, o čemu svjedoči napis seljaka iz toga sela koji žali što je Andrija Štampar morao otići, ali tvrdi da ih je podučio kako se boriti protiv alkoholizma. U tijeku iste godine u Karlovcu je radio kao liječnik i 1. listopada 1911. započeo je s ciklusom predavanja na temu Alkohol, njegovo djelovanje i borba protiv njega, a još je nekoliko predavanja održao i tijekom 1912. godine. Pod njegovim je vodstvom s radom započela i apstinentska mjesna organizacija. ${ }^{166}$

U isto vrijeme nastajala su i prva laička društva učitelja i omladine pa su tako 1911. godine u Pragu hrvatski studenti osnovali Antialkoholni odjel, a u Pakracu je formirano Udruženje učenika apstinenata pripravnika na srpskoj preparandiji "Pobratimstvo"167 i Udruženje đaka apstinenata "Budućnost” iz Karlovca. ${ }^{168}$ Učitelji su često u tekstovima pisanima za Novi život govorili o uzrocima i potrebama osnivanja apstinencijskih pokreta. Pogotovo su se referirali na činjenicu da su takvi pokreti najpotrebniji učenicima i seljaštvu jer intelektualci apstinencijski pokret nisu prihvatili. Učitelji su trebali biti upoznati s ulogom pokreta jer su djeca već u pučkim školama

163 Jandrić-Balen, Balen, “Andrija Štampar i borba protiv alkoholizma”, 86.

164 Jandrić-Balen, Balen, “Andrija Štampar i borba protiv alkoholizma”, 67-72. Riječ je o člancima: "Alkohol", Materinska riječ: glasilo hrv.-srp. koalicije (1907-8): 5; "Ne dajte djeci žestokih pića", Materinska riječ (1907-1908): 4; "Alkohol s medicinskog gledišta”, Svjetlost 4 (1908): 35-38; "Djelovanje alkohola na tijelo", u: Knjižnice za narodno zdravlje II, Žestoka pića, ur. Milivoj Mlađan (Nova Gradiška: Štamparija M. Mladjana, 1909); “Alkohol”, Hrvatski đak 3 (1908): 80-85; "Rad oko dizanja narodnog zdravlja", Zvono: opća smotra, (1909): 68; "Dan austrijskih antialkoholičara”, Liječnički vjestnik 30 (1908): 388-390; “Teški porezi”, Pučka prosvjeta (1911): 69-70; "Dvije uspomene- dvije slave”, Hrvatski pokret 7 (1911): 5-6.

165 Jandrić-Balen, Balen, "Andrija Štampar i borba protiv alkoholizma”. "Sokoli i borba protiv alkohola”, Narodni glas 7 (1912); “Nešto o alkoholu”, Crveni kalendar 5 (1912): 78-79; "Kako djeluje alkohol na čoveka", Srbobran 4 (1912): 4-5; "Alkoholizam u Hrvatskoj i borba za trezvenost", Trezvenost 5 (1912): 22-26; "Sokoli i borba protiv alkohola”, Hrvatski sokolski kalendar 8 (1913): 46-48.

166 Dr. D. Šašel, "Lijepe pojave. Apstinencijski pokret u Karlovcu”, Novi naraštaj, list za suzbijanje opojnih pića, za školu i dom 4 (1912): 58.

167 "Protualkoholni pokret među omladinom. Pobratimstvo", Novi život glasilo: Društva apstinenata u Hrvatskoj i Slavoniji 2 (1914): 22-23. Društvo je osnovano 30. 9. 1911. Svrha je udruženja: očuvanje zdravlja, trezvenost, borba protiv alkoholnih pića, širenje općih higijenskih pravila. Dva puta mjesečno dolazi do sastanaka, održavaju se predavanja, društvo ima knjižnicu.

168 “Škola i alkohol. Naše đaštvo i apstinencijski pokret”, Novi život: glasilo Društva apstinenata u Hrvatskoj i Slavoniji 12 (1913): 186. 
konzumirala alkohol ${ }^{169}$ Osim u učiteljskim i omladinskim grupacijama o alkoholizmu i apstinencijskome pokretu oglašavalo ${ }^{170}$ se i u Sokolskome savezu gdje je dr. Šašel u Hrvatskome sokolu pozivao na apstinencijski pokret po uzoru na djelovanje praških sokola u sklopu sokolskoga pokreta.

Usporedno s djelovanjem liječnika i učitelja na protualkoholnome pokretu djelovale su i vjerske organizacije poput Katoličke Crkve, franjevaca, Pakračke eparhije kao i Hrvatsko-slavonskoga evangeličkog vjerskog seniorskog ureda iz Osijeka. Katolički protualkoholni pokret nastao je pod utjecajem slovenskoga katoličkog apstinencijskog pokreta, ${ }^{171}$ koji je bio pod vodstvom svećenika Janeza Kalana i koji je vodio organizaciju Sveta vojska i časopis Zlata Doba. ${ }^{172}$ Djelovanje Janeza Kalana utjecalo je na činjenicu da su i zagrebački bogoslovi 1907. godine osnovali Apstinencijski klub i tiskali knjižicu Najveći neprijatelj čovječanstva - alkohol kao što su i franjevci 1910. godine tiskali Borimo se, dok je vremena. Katolička omladina u društvu Domagoj osnovala je u isto vrijeme i svoju apstinencijsku skupinu koja je okupljala oko dvjesto članova te se također bavila izdanjima protualkoholne tematike. Poticaj za daljnji rad dao je angažman pape Pija X. koji je u 1914. godini pozvao na osnivanje "Svete vojske" u Brezju. ${ }^{173}$ Potkraj 1914. godine kapucini u Rijeci osnovali su prvu hrvatsku podružnicu "Svete vojske," koju je činilo 58 potpunih apstinenata. ${ }^{174}$

Tijekom 1912. Pravoslavna Crkva na području Pakračke eparhije svojom je poslanicom vjernike upozorila na štetnost alkohola i pojave alkoholizma, ${ }^{175}$ dok je Hrvatsko-slavonski evangelički vjerski seniorski ured iz Osijeka 1904. godine ozbiljnije shvatio problem alkoholizma te je čak uputio Vladi Prijedlog kako da se alkoholu na put stane. ${ }^{176} \mathrm{U}$ navedenome Prijedlogu naznačeno je kako je alkoholizam velik problem te kako bi se mogao suzbiti samo ako bi se protiv toga problema formirale savjetodavne komisije, koje bi organizirali učitelji, svećenici, suci i policija. Također je u sedamnaest točaka razrađen plan praktičnoga postupanja u svrhu suzbijanja alkoholizma. U tim je točkama navedeno kako bi se trebali braniti: ulazak djeci do 14 godina u gostionice, konzumacija alkohola djeci do 14 godina, posjećivanje lokala pijanim osobama i boravak pijanih osoba na ulici te kako gostioničari ne bi trebali

169 Jure Cindrić, "Učitelji u borbi protiv alkohola”, Novi život: glasilo Društva apstinenata u Hrvatskoj i Slavoniji 4 (1913): 58-61. Cindrić je smatrao kako su učitelji bili ti koji su mogli nešto učiniti u odgoju mladeži i djece u školi učeći ih o štetnosti alkohola. Prema Cindrićevu navođenju od dvjesto djece koja su pohađala školu nije bilo djeteta koje u najranijoj dobi nije pilo alkohol.

170 Dr. D. Šašel, “Sokolstvo i alkoholizam”, Novi život: glasilo Društva apstinenata u Hrvatskoj $i$ Slavoniji 6 (1913): 58.

171 Studen, Pijane zverine, 106, 125. Začetke toga pokreta moguće je već pronaći 1840. godine u djelovanju slovenskoga biskupa Antona Martina Slomšeka.

172 “Apstinencijski pregled. Katolički pokret među Slovencima i Hrvatima”, Novi život: glasilo Društva apstinenata u Hrvatskoj i Slavoniji 12 (1913): 184.

173 Krašić, "Djelovanje kapucinskog protualkoholnog društva 'Sveta vojska”, 136.

174 Krašić, "Djelovanje kapucinskog protualkoholnog društva 'Sveta vojska”, 136.

175 Episkop Miron, "Poslanica o alkoholu”, Novi život: glasilo Društva apstinenata u Hrvatskoj $i$ Slavoniji 4 (1913): 50-52.

176 HR - Hrvatski Državni arhiv(dalje: HDA) - fond 79 (dalje: 79) - Zemaljska vlada, Odjel za unutarnje poslove (dalje: UOZV) - 77016, 13 - 27, 1009./1904. 
točiti žestoka pića tako da se gost od toga opije. Potom su se neke točke odnosile na uredovno vrijeme rada gostionica i točenja alkohola te na kaznene odredbe u slučaju kršenja svega navedenog. Svi navedeni sporadični protualkoholni pokreti bili su reakcije istaknutih liječnika, svećenika i učitelja koji su uočavali kako je sve masovniji alkoholizam hranjen mnoštvom društvenih stereotipa i kako je jedva zamjetno zakonski sankcioniran.

\section{Organiziranje i djelovanje Društva apstinenata u Kraljevini Hrvatskoj i Sla- voniji te u Kraljevini Dalmaciji}

Tijekom travnja 1911. dolazi do organiziranja Društva apstinenata koje je odlučilo da časopis Novi naraštaj, list za suzbijanje opojnih pića, za školu i dom postane službeni list Društva. Iako je izlazio i na latinici i na ćirilici te je od 1912. godine imao velik broj pretplatnika, nakon nekoga vremena časopis je, zbog neslaganja s koncepcijama uprave Društva apstinenata u Hrvatskoj i Slavoniji, prestao biti službeni. ${ }^{177}$ U kolovozu 1912. godine sastavljena su Pravila Društva i poslana su Vladi na odobrenje, a službeni naziv društva glasio je Društvo apstinenata u Kraljevini Hrvatskoj i Slavoniji. ${ }^{178}$ Prema podatcima Prve skupštine Društva apstinenata, održane 28. travnja 1912., na području Kraljevine Hrvatske i Slavonije bilo je 50000 alkoholičara, ${ }^{179}$ što je tada činilo oko 2 \% ukupnoga broja stanovnika Kraljevine. Također, na alkohol se godišnje trošilo 70.000.000 kruna, što je iznosilo oko 28 kruna godišnje po osobi. Prema koncepciji Novoga naraštaja glasilo je pokušalo tijekom 1912. godine "pokriti” više tema poput školstva i alkoholizma, djelovanja u susjednim zemljama, rada na suzbijanju alkoholizma, književnosti, o djelovanju podružnica i slično. Početkom 1913. godine izašla su dva protualkoholna lista, staro glasilo Novi naraštaj, čiji je urednik bio Nikola Đurić i novo službeno glasilo Društva apstinenata Novi život, čiji je urednik bio dr. Andrija Štampar. Koncepcija novoga glasila temeljila se na ideji produktivnijega i organiziranijega rada, a time i većega utjecaja na čitateljstvo, pa je stoga strukturno bilo podijeljeno na nekoliko tema: "tema broja, apstinencijski pregled, škola i alkohol, radništvo i alkohol, država u borbi protiv alkohola, alkoholizam i vojništvo, književnost i bilješke." 180

177 “Apstinencijski pregled. Nemila pojava”, Novi život: glasilo Društva apstinenata u Hrvatskoj $i$ Slavoniji 5 (1913): 73. Andrija Štampar navodi razloge prekidanja suradnje s Nikolom Đurićem. U Društvu se smatralo da časopis ne izlazi dovoljno redovito iako je postojala potražnja. Na odborskoj sjednici odlučeno je o raskidanju odnosa Društva s časopisom Novi naraštaj te o osnivanju novoga lista kojemu bi Društvo bilo vlasnik. S 1. 1. 1913. započeo je izlaziti časopis Novi život. Nikola Đurić nastavio je izdavati časopis Novi naraštaj i deklarirao ga je kao glasilo Apstinencijskoga društva iako više nije imao potporu Društva.

178 “Apstinencijski pregled. Što se u Hrvatskoj učinilo proti alkoholizmu?”, Novi život: glasilo Društva apstinenata u Hrvatskoj i Slavoniji 1 (1913): 8.

179 "Rad na suzbijanju opojnih pića. Prva glavna skupština Društva apstinenata u Hrvatskoj i Slavoniji”, Novi naraštaj, list za suzbijanje opojnih pića, za školu i dom 5 (1912): 76.

180 Novi život: glasilo Društva apstinenata u Hrvatskoj i Slavoniji (1913). 
Tijekom 1913. godine protualkoholičarski se pokret proširio Kraljevinom pa je tako rad na području Križevaca organizirao Fran Gudrum Oriovčanin, na području Karlovca Andrija Štampar, u Staroj Gradiški Dositije Kutuzov, u Srijemskoj Mitrovici Milan Kostić, a u okolici Rijeke predavanja je držao Ivan Kiseljak. ${ }^{181}$ Sredinom iste godine pokreti apstinenata ili "trezvenjaka” počeli su se masovno organizirati diljem Like i Banovine, a u Slavoniji i Zagorju težilo se povećanju broja članova. Tako je podružnica Društva apstinenata za Slavoniju osnovana u Novoj Gradiški. U isto vrijeme Nikola Đurić napisao je edukativnu knjižicu o alkoholu Trezvenost je moj ponos u sklopu projekta Knjižnica proti alkoholu. Društvo novogradiških trezvenjaka izdalo je 1913. godine Đurićevu propagandnu knjižicu Novi pogledi. ${ }^{182}$ Osim izdavačke djelatnosti Društvo je organiziralo i prvu izložbu ${ }^{183}$ tijekom kolovoza i rujna 2012. godine u realizaciji karlovačke podružnice. Izložba je ostvarena u suradnji sa Sokolima i češkim apstinencijskim pokretom te je na njoj predočeno djelovanje Češkoga apstinencijskog društva, mnoštvo kemijskih pokusa i propagandnoga materijala. Iako je Društvo formalno djelovalo tijekom čitave 1912. godine, ono nije naišlo na velik odaziv ni u krugovima intelektualaca ni u krugovima liječnika, ${ }^{184}$ nego je svoj najveći utjecaj imalo na obrtništvo, seljaštvo i učenike. Usprkos tomu, financirano samo iz vlastitih izvora, Društvo je nastavilo tiskati svoj časopis i tijekom 1914. godine na temelju dovoljnoga broja pretplatnika.

Apstinencijski pokret kao ni rad Društva nisu bili podržani adekvatnom legislativom s obzirom da je samo Banska naredba od 23. prosinca 1900. godine br. 87363 (više u savjetodavnome tonu) upućivala na uputno ponašanje smatrajući konzumaciju alkohola tek nepoželjnom. Borba protiv alkoholizma većinom je bila na savjetodavnoj razini te su tako 1913. godine Zagrebačka i Karlovačka županija uputile Proglas o mjerama koje se trebaju provoditi sa svrhom suzbijanja alkoholizma. Riječ je o mjerama poput težnje za organiziranom borbom protiv alkoholizma u obliku osnivanja apstinencijskih društava, apostrofiranja važnosti borbe protiv umjerenoga uživanja u alkoholu, obrazovanja svih slojeva društva kao i donošenja adekvatne legislative temeljene na umjerenoj prohibiciji. Iz navedenih se mjera uočava kako su poticaji za djelovanje Zagrebačke i Karlovačke županije bili iznimka jer takve proglase druge županijske i kotarske vlasti nisu upućivale zato što takve inicijative nisu postojale na razini Kraljevina, a također se uočava kako je samo pretjerano uživanje u alkoholu tada smatrano štetnim, dok se umjereno uživanje toleriralo, zbog čega je pokret i smatrao bitnim mijenjati uvriježena mišljenja o alkoholu. Potkraj 1913. godine osnovana je zagrebačka podružnica Apstinencijskoga društva koja je imala 25 članova. Najbrojnija je bila podružnica u Karlovcu s 36 članova, dok je ona na Sušaku imala

181 "Rad na suzbijanju pijanstva", Novi naraštaj, list za suzbijanje opojnih pića, za školu i dom 1 (1913): 6-7.

182 Nikola Đurić, Novi pogledi.

183 "Apstinencijski pregled. Izložba proti alkoholu u Karlovcu", Novi život: glasilo Društva apstinenata u Hrvatskoj i Slavoniji 2 (1913): 24. Na izložbi je tijekom tri dana bilo 260 posjetilaca.

184 Andrija Štampar, "Liječnici i alkoholno pitanje”, Novi život: glasilo Društva apstinenata u Hrvatskoj i Slavoniji 10 (1913): 147. 
32 člana. ${ }^{185} \mathrm{Na}$ kraju 1913. godine održano je predavanje u Opatiji na kojemu je bilo mnoštvo interesenata iz Istre. Glavni cilj društva za 1914. godinu bila je organizacija velike protualkoholne izložbe u Umjetničkome paviljonu.

Osim zagrebačke podružnice potkraj 1913. godine osnovano je "Društvo za suzbijanje alkoholizma u Imotskoj krajini." 186 Predsjednik društva bio je dr. Grga Bogić, a društvo je imalo trideset članova od kojih je bilo sedamnaest apstinenata. Društvo je namjeravalo držati protualkoholna predavanja, distribuirati propagandne letke i plakate te surađivati sa školama i liječnicima na edukaciji stanovništva. Tijekom 1914. godine u Splitu je otvorena prva bezalkoholna trgovina. ${ }^{187}$ Apstinencijski je pokret u Dalmaciji tijekom 1914. zaživio pa je tako Pokrajinsko školsko vijeće zatražilo izvješća pučkih škola i kotarskih školskih vijeća o alkoholizmu kod školske djece, ${ }^{188}$ potom je Društvo apstinenata u Imotskome planiralo imati stalnu izložbu u jednoj prostoriji škole, a Ravnateljstvo pošta u Zadru dopustilo je lijepljenje apstinencijskih plakata u poštanskim uredima. ${ }^{189}$ Učitelji u Imotskome organizirali su takozvane trezvene čete učenika, a u Stonu su se dijelile brošure učenicima o protualkoholnom djelovanju. ${ }^{190}$

\section{Protualkoholna izložba u Zagrebu 1914.}

Potkraj 1913. godine započete su pripreme za izložbu naziva "Proti alkoholu” čije je otvorenje bilo predviđeno 1. ožujka 1914. u Umjetničkome paviljonu u Zagrebu. Prije izložbe tiskani su plakati i letci "Klonimo se žestokih pića” i "Zašto smo apstinenti". ${ }^{191}$ Izložba je bila međunarodnoga karaktera te su na njoj sudjelovali domaći i inozemni stručnjaci, pogotovo iz susjednih zemalja. Cilj je izložbe bio upozoriti na problem alkoholizma, ali i pokazati što je protualkoholni pokret u Hrvatskoj napravio. Izložba je otvorena 8. ožujka $1914 .{ }^{192}$ u 10 sati i, osim toga što je prezentirala rad protualkoholnoga društva, predavanjima je potaknula na borbu protiv alkoholizma kao što je bio i planiran razvoj socijalnoga muzeja. ${ }^{193}$ Prvoga dana izložbu je posjetilo oko tisuću

185 “Apstinencijski pregled. Osnutak podružnice Društva apstinenata u Zagrebu”, Novi život: glasilo Društva apstinenata u Hrvatskoj i Slavoniji 11 (1913): 173-174.

186 "Protualkoholni pokret među Hrvatima", Novi život: glasilo Društva apstinenata u Hrvatskoj i Slavoniji 8/9 (1914): 152. Riječ je o prvome takvom apstinentskom društvu u Dalmaciji.

187 "Bezalkoholni lokal u Dalmaciji”, Novi život: glasilo Društva apstinenata u Hrvatskoj i Slavoniji 1 (1914): 12. Novi život je do kraja 1913. godine imao ukupno 346 pretplatnika. U Hrvatskoj je imao 299 pretplatnika, u Bosni 28, u Dalmaciji devet, u Beču osam, u Ugarskoj jednoga, a u SAD-u imao je također jednoga pretplatnika.

188 "Protualkoholni pokret među Hrvatima", Novi život: glasilo Društva apstinenata u Hrvatskoj $i$ Slavoniji 8/9 (1914): 154

189 “Iz Dalmacije", Novi život: glasilo Društva apstinenata u Hrvatskoj i Slavoniji 2 (1914): 29.

190 "Iz Dalmacije", 29.

191 “Apstinencijski pokret. Što je izvršilo Društvo apstinenata u Hrvatskoj i Slavoniji u g. 1913?”, Novi život: glasilo Društva apstinenata u Hrvatskoj i Slavoniji 1 (1914): 11. Društvo je tiskalo letke u deset tisuća primjeraka. Prvi letak govori o tome zašto je alkohol štetan za ljudski organizam, a drugi letak govori o osobnim motivima dr. Kiseljaka. Cijena je svakoga letka bila četiri forinte.

192 "Apstinencijski pokret", 45.

193 "Apstinencijski pokret", 45. Usporedo s procesom pripreme za izložbu prikupljala se i građa za otvorenje Socijalnoga muzeja. 
posjetitelja. Kustos izložbe bio je inženjer Dušan Birač, a dr. Kiseljak zajedno s dr. Štamparom bio je tumač raznih događanja i predavanja. U uvodnoj riječi predsjednik Društva apstinenata dr. Ivan Kiseljak predstavio je povijest Društva, istaknuo je važnost izložbe kao i njezinu utemeljenost na modernim znanstvenim i statističkim dostignućima, a sve radi prenošenja jasne poruke o štetnosti alkoholizma koju podržavaju moderne države. Na kraju izlaganja zahvalio je inozemnim gostima, tj. Slovačkome apstinencijskom savezu Janeza Ev. Kalana, ${ }^{194}$ izaslaniku Društva srpskih ljekara apstinenata i Srpskih Guttemplara dr. M. Đ. Popoviću ${ }^{195}$ te izaslaniku Ugarskoga zemaljskoga protualkoholnog društva prof. dr. Gyulu Szakayu, ali i svima ostalima poput banu Škrlecu, banskim savjetnicima, župniku Jelačiću, općinskome načelniku, Hrvatskome liječničkom zboru, Hrvatskome sokolskom savezu, Hrvatskome pedagoškom zboru, Udruzi učiteljica, Ligi za zapuštenu djecu i mnogima drugima. ${ }^{196}$

Ban Škrlec otvorio je izložbu. Izložba je bila otvorena do 16. travnja 2014., a nakon toga datuma samo nedjeljom i blagdanom. Od gostiju su na otvorenju izložbe govorili: u ime Hrvatskoga liječničkog zbora dr. Miroslav Čačković i to o štetnosti alkohola, potom dr. Gyula Szalkay kao izaslanik Ugarskoga zemaljskog protualkoholnog društva o otvorenju izložbe kao važnome koraku u borbi protiv alkoholizma te nakon njih župnik Janez Ev. Kalan iz Slovenije kao izaslanik Slovenskoga apstinencijskog saveza 'Sveta vojska' o važnosti pokreta i radu katoličke misije.

Koncepcija izložbe bila je zamišljena tako da se upozori na sve učestaliji problem alkoholizma u svakodnevici koji je utjecao na mnogo segmenata društva. Istodobno je izložba ciljala i na stručni kadar kao i na običan puk predočujući raznovrsnu građu poput grafika, slika, plakata, tablica i literature. Već sâm autor teksta ${ }^{197}$ na izložbi je uočio manjak estetskih obilježja izložbe ističući prije svega njezinu informativno-obrazovnu ulogu. Izložba je za glavni cilj imala osvješćivanje i obrazovanje stanovništva o problemu alkoholizma kao relativno novootkrivenome problemu u hrvatskome društvu.

Koncepcija izložbe pratila je probleme koje alkoholizam izaziva u društvu pa je tako izložba tematizirala i povezanost alkohola i različitih društvenih segmenata. Izložba se prema tablicama dijelila na: "Alkohol i zločin", "Alkohol i degeneracija", "Alkohol i bolesti", "Alkohol i pomor," "Alkohol i duševni rad," "Alkohol i škola," "Alkohol i kućanstvo," "Alkohol i država." Potom se na izložbi moglo vidjeti mnoštvo edukativnih prikaza koji su slikovno negirali u narodu sve prihvaćene krilatice "Alkohol-hrani, alkohol-ozdravljuje” pa je tako prikazana hranjivost raznih vrsta namirnica, ali i alkohola, kao i utjecaj alkohola na zdravlje pojedinih organa. Nadalje, na izložbi su bile

194 "Protualkoholna izložba u Zagrebu”, Novi život: glasilo Društva apstinenata u Hrvatskoj i Slavoniji 4 (1914): 50. Izaslanik Slovačkoga apstinencijskog Saveza. Predsjednik “Zveze Sveta Vojska” i urednik "Zlate Dobe."

195 "Protualkoholna izložba u Zagrebu”, 50. Izaslanik Društva srpskih ljekara apstinenata i srpskih Guttemplara, liječnik i urednik "Trezvenosti” i "Saveznika."

196 "Protualkoholna izložba u Zagrebu”, 50.

197 Vladimir Pfeifer, "Protualkoholna izložba u Zagrebu. Opis izložbe”, Novi život: glasilo Društva apstinenata u Hrvatskoj i Slavoniji 4 (1914): 52-57. 
prikazane "slike"198 nedavnih događaja povezanih s uživanjem alkohola, a riječ je o seriji od devet prikaza kojima se ilustriraju događaji u Slavoniji, Austriji i Trstu. Riječ je o nesrećama više ljudi sa smrtnim ishodom koji je bio rezultat uživanja u alkoholu. Potom je izložen ispis iz Dušanova zakonika koji govori o zločinu počinjenome u alkoholiziranome stanju. Posljednji dio izložbe odnosio se na literaturu u vezi s temom alkohola i alkoholizma, koja je tiskana u Sloveniji, Hrvatskoj i Srbiji, kao i na izreke te narodne poslovice koje su prikupljene o toj temi. Možda i najvažniji dio izložbe govori o alkoholizmu u kontekstu Kraljevine Hrvatske i Slavonije te se tu ističe kako se godišnje na alkoholna pića troši osamdeset milijuna kruna. Izložba je bila popraćena raznovrsnim stručnim predavanjima. ${ }^{199}$

Predavanja su započela 8. travnja, a na prvome su predavanju govorili Janez Ev. Kalan o alkoholizmu i klerikalnome pokretu, a Đ. M. Popović održao je predavanje "Alkohol u Balkanskom ratu”. Ostala su predavanja održana ovim redom: 9. travnja dr. Gyula Szalkay, izaslanik Saveza mađarskih apstinencijskih udruženja "O protualkoholnim organizacijama u Ugarskoj, njihovoj borbi i sudbini”; 10. travnja dr. Andrija Štampar, Nova Gradiška "Alkohol s liječničkog gledišta”; 11. travnja "Alkohol i radništvo"; 12. travnja dr. Ivan Kiseljak, Rijeka “Zašto smo apstinenti?”; 13. travnja dr. Dragan Šesel, Karlovac "O protualkoholnom pokretu s pravnog gledišta uz prikaz apstinencijskog pokreta u Finskoj”; 15. travnja dr. F. S. Gudrum, Križevci “O alkoholnom pitanju uopće"; 22. travnja dr. Josip Šilović "Pijanstvo i zločin". 200

Trošak izložbe koja je bila rezultat tada novoosnovanoga Socijalnog muzeja ${ }^{201}$ i Društva apstinenata iznosio je 1200 kruna. Nakon zatvaranja izložbe Društvo apstinenata odlučilo je organizirati dvije putujuće izložbe, a nakon toga svi su izlošci ostali u vlasništvu Društva. Rezultati te izložbe bili su vidljivi u edukaciji velikoga broja posjetitelja, predavanjima, u osnivanju Socijalnoga muzeja kao što je i sama izložba bila poticaj za daljnji rad apstinencijskoga pokreta.

U mnogim je novinama informativno pisano o otvaranju izložbe, a pozornost posebice privlači satiričan tekst podlistka naslova "Antialkoholaši” objavljen u Nezavisno$s t i{ }^{202}$ Kao što autor sâm objašnjava, nije mu bilo jasno što se na takvoj izložbi izlaže kao ni kakav tip publike takva izložba može privući pa se morao sâm uvjeriti u antialkoholizam koji je on, s obzirom na hrvatski kontekst, nazvao umjetnom stvari. Autor je uočio da su žene najbrojnija publika na izložbi, ali da je bilo i muškaraca, mladih, koji su protiv alkohola jer nedjeljom rade, muškaraca srednje dobi, koji već imaju crvene nosove, te starih muškaraca kojima je želudac već toliko pokvaren "da više ne mogu da piju". Simbolični dijalog koji je autor satire vodio sa "starim Hrvatom"203

\footnotetext{
198 Neke vrste ilustracija ili fotografije nedavnih događaja.

199 "Protualkoholna izložba u Zagrebu”, Novi život: glasilo Društva apstinenata u Hrvatskoj i Slavoniji 5 (1914): 72-75.

200 "Protualkoholna izložba u Zagrebu", 74.

201 "Protualkoholna izložba u Zagrebu”, 74. Organiziran u Trenkovoj ulici br. 1, II. kat, lijevo.

202 “Antialkoholaši”. Nezavisnost, Bjelovarsko-križevački vjesnik (Bjelovar) 14. 3. 1914., 1. Preuzeto iz Obzora (Zagreb), 10. 2. 1914., 1.

203 "Antialkoholaši”, 1. Navodi da je riječ o nekome vitezu.
} 
govori o drukčijemu viđenju protualkoholnoga pokreta, prema kojemu su "pravi stari Hrvati" bili ljubitelji vina. Autor satire tješi "staroga Hrvata" da "Ako o tome ovisi hrvatstvo - nikad ne će izginuti." "Stari Hrvat" u tekstu, osim toga što nacionalizam povezuje s uživanjem alkohola, povezuje alkohol is patriotizmom, oduševljenjem i odlučnošću. Uvidjevši prisutnost političkih elita, starac biva razočaran i oprašta se od takve Hrvatske. Satira završava razlazom publike i dijalozima na izlasku iz Umjetničkoga paviljona u kojima se ističe daljnji tijek druženja publike s Antialkoholne izložbe. Mladi navode da idu dalje u pivnice, "stari Hrvat" da ide dalje na konjak da pripremi želudac za objed, a gorljivi je antialkoholičar svima vikao "Sramota!" "U načelu sam protiv alkohola, a u praksi (...) Ja idem doma da mi skuhaju Glihtvein!" Svoju je satiru pisac završio narodnim napjevom: "Ništa na svijetu goršega ni - Nego kad vinca rujnoga fali..." Iako je navedena satira samo površna slika razumijevanja protualkoholnoga pokreta, paralelni izvori govore da ni u stručnim krugovima pokret nije naišao na adekvatno razumijevanje kao što je to bio slučaj sa susjednim zemljama gdje je zahvaljujući legislativi bio ozbiljnije primljen. A ukoliko se povuče paralela sa suvremenim razumijevanjem apstinencije od alkohola, uočava se kako je s vremenom stvorena visoka razina tolerancije prema uporabi alkoholnih pića i mala prema apstinenciji. ${ }^{204}$

Daljnji rad Društva apstinenata do kraja 1914. godine išao je u smjeru mogućih dogovora sa seljačkim ${ }^{205}$ i zemljoradničkim organizacijama ${ }^{206}$ koje su trebale sudjelovati $\mathrm{u}$ radu protualkoholnoga pokreta, potom stvaranja omladinskih organizacija ${ }^{207}$ te $\mathrm{u}$ daljnjemu osvješćivanju stanovništva o važnosti protualkoholnoga i apstinencijskoga pokreta. ${ }^{208}$ Tijekom 1914. godine održan je i IV. Austrijski protualkoholni kongres, ${ }^{209}$ na kojemu su prvi put sudjelovali i Hrvati. Taj kongres, za razliku od prethodnih triju, održan je na češkome i njemačkome jeziku pa je hrvatski delegat dr. Dragan Šašel ${ }^{210}$ izlaganje trećega dana održao na češkome jeziku o protualkoholnome radu

204 Štifanić,“Alkoholizam i društvene znanosti”, 703.

205 “Središnja sveza hrvatskih seljačkih zadruga u Zagrebu i naš pokret”, Novi život: glasilo Društva apstinenata u Hrvatskoj i Slavoniji 8/9 (1914): 124-125. Na sjednici Hrvatskih seljačkih zadruga u Zagrebu odlučeno je da nadzornici tih zadruga izvijeste o stanju alkoholizma u zadrugama te da ako utvrde da postoji velik broj alkoholičara, onda Društvo apstinenata održi predavanja na tu temu.

206 “Središnja sveza hrvatskih seljačkih zadruga u Zagrebu i naš pokret”, 124 -125. Savezom hrvatskih seljačkih zadruga i Savezom srpskih zemljoradničkih zadruga.

207 “Apstinencijski pregled. Iz Društva apstinenata u Hrvatskoj i Slavoniji”, Novi život: glasilo Društva apstinenata u Hrvatskoj i Slavoniji 5 (1914): 76-77. Odnosilo se na stvaranje organizacije među sveučilišnom omladinom u Zagrebu.

208 “Kako mi u Karlovcu promičemo protualkoholnu misao?”, Novi život: glasilo Društva apstinenata u Hrvatskoj i Slavoniji 8/9 (1914):126. U Karlovcu je Društvo pokušalo na nov i zanimljiv način potaknuti interes kod građanstva tako što su na ulicu postavili ormarić sa staklom unutar kojega su izlagali razne oglase, plakate, novine i slično sa svrhom da izazovu interes i reakciju stanovništva na problem alkoholizma.

209 "IV. austrijski protualkoholni konges", Novi život: glasilo Društva apstinenata u Hrvatskoj i Slavoniji 7 (1914): 110-111.

210 "IV. austrijski protualkoholni konges", 110-111. Zastupao je "Društvo za suzbijanje alkoholizma u Imotskoj krajini" i bio izaslanik "Društva apstinenata u Hrvatskoj i Slavoniji”. 
u Hrvatskoj. Od rujna je - zbog ratnih prilika - izdan dvobroj "Novoga života", a u studenome je objavljen trobroj "Novoga života". ${ }^{211}$ U navedenim brojevima sve su više bile zastupljene teme o ratu, vojsci i alkoholu, čime se uredništvo "Novoga života" pokušalo prilagoditi novonastaloj ratnoj situaciji kako bi tematski bili što bliže čitateljima.

\section{Zaključak}

Borba protiv alkohola stara je koliko je star i alkohol, ali moderno protualkoholno djelovanje nastalo je na području Trojedne Kraljevine u Slavoniji kao posljedica uočavanja poražavajuće prakse pijenja alkoholnih pića u mnogim prilikama. Običaj pijenja alkoholnih pića kontinuirano je bio prisutan i uvjetovan tradicijom, radom i poljoprivrednim kulturama, ali tek je s bolestima vinove loze i industrijskom proizvodnjom alkoholnih pića poremećena krhka ravnoteža u umjerenosti pijenja. Austro-Ugarska je, u usporedbi s drugim europskim zemljama, kasnila u legislativi potičući nizak porez i time pogodujući industrijama, a sve na štetu malih proizvođača alkoholnih pića te, posljedično, time potičući alkoholizam. Nakon 1888. godine etanol se ponovno počeo konzumirati, a budući da je bio dostupniji i jeftiniji nego šljivovica, stanovništvo ga je razrjeđivalo te je dobivalo alkohol za konzumaciju. O sprezi siromaštva i alkoholizma već je u 18. stoljeću pisao Reljković upozoravajući kako seljak nije obrazovan, a da bi se mijenjao. Prepoznavši socijalno-ekonomske čimbenike poput neadekvatnoga obrazovanja, običaja pijenja alkoholnih pića u raznim prilikama, stereotipe i siromaštvo kao otegotne, Fran Gudrum Oriovčanin, Nikola Đurić i Andrija Štampar razradili su program borbe protiv alkoholizma već 1906. godine okupivši se oko prvoga protualkoholnog časopisa. Tada se rodila ideja o prvome Društvu apstinenata, koja je realizirana tek 1912. godine. Budući da je kultura prekomjernoga pijenja alkoholnih pića u Trojednoj Kraljevini bila općeprihvaćena i sveprisutna te nije prepoznata kao potencijalna ugroza čak niti od vladajućih i stručnih elita, propagiranje protualkoholne borbe moralo je biti utemeljeno na spoznajama moderne znanosti i statistike po uzoru na druge europske zemlje. Svoj rad Društvo je baziralo na tiskanju publikacija, letaka i brošura, organiziranju podružnica, sudjelovanju hrvatskoga delegata na Antialkoholnome kongresu u Brnu 1914., organiziranju sastanaka i predavanja apelirajući pri tom na učitelje, liječnike, svećenstvo i trgovce da pokušaju zajedno s društvenom elitom mijenjati stereotipe i običaje stanovništva. Nevjerojatni brojevi o potrošnji alkoholnih pića upućivali su na težinu problema koje je Društvo pokušalo opredmetiti organiziranjem Antialkoholne izložbe u Zagrebu 1914. godine. Društvo je organiziranjem Antialkoholne izložbe i sudjelovanjem na Antialkoholnome kongresu pokazalo kako je bilo dio europskih protualkoholnih tendencija čime je i udarilo temelje onoga što je tek u poslijeratnoj protualkoholnoj borbi realizirano.

211 “Apstinencijski pregled”, Novi život: glasilo Društva apstinenata u Hrvatskoj i Slavoniji 8/9 (1914): 123. 
Pojedinci u Društvu apstinenata već su tada razumjeli kako je alkoholizam problem obitelji i zajednice u čijemu rješavanju moraju sudjelovati svi dionici i interesenti te su mu pristupili kao bolesti koju treba rješavati na mnogo društvenih razina. U razumijevanju alkoholizma vodili su se krilaticom kako samo zdrava država teži imati zdrave građane. 


\section{Neobjavljeni izvori}

Hrvatska - Hrvatski Državni arhiv - fond 79 - Zemaljska vlada, Odjel za unutarnje poslove (HR-HDA-79-UOZV).

Hrvatska - Državni arhiv u Slavonskom Brodu - Odjel Nova Gradiška - fond Školske spomenice (HR-DASB-ONG-FŠS).

\section{Objavljeni izvori i literatura}

1875. - 1915. Statistički atlas Kraljevina Hrvatske i Slavonije. Zagreb: Tisak i litogr. Kr. zem. tiskare, 1915.

“Akov", Hrvatski leksikon. Pristup ostvaren 1. 3. 2015. http://www.hrleksikon.info/definicija/akov.html .

Anić, Vladimir; Brozović-Rončević, Dunja; Goldstein, Ivo; Goldstein, Slavko; Jojić, Ljiljana; Matasović, Ranko; Pranjković, Ivo; Samardžija, Marko. Hrvatski enciklopedijski rječnik. Zagreb: Novi liber, 2002.

Bales, F. Robert. "Cultural differences in rates of alcoholism". Quarterly Journal of Studies on Alcohol 6 (1946.), br. 4: 480-499.

Banovac, list za pouku, trgovinu, obrt i gospodarstvo (Petrinja), 1893.

Bašić, Želimir. Voda života: povijest proizvodnje jakih alkoholnih pića. Šibenik: Tiskara Malenica, 2006.

Bašić, Želimir. Dalmatinska vina kroz stoljeća: dalmatinsko vinogradarstvo i podrumarstvo $u$ rasponu vremena u legendama, umjetnosti, pravnim normama $i$ činjenicama. Šibenik: Tiskara Kačić, 2001.

Bašić, Želimir. Prošlost dalmatinskog vinarstva. Prilozi za povijest vinogradarstva, vinarstva $i$ vinarskih zadruga Hrvatske. Split: vlast. nakl., 2018.

Bogavčić Salopek, Iva. “Novogradiški kotar 1886. - 1914.”. Doktorska disertacija, Sveučilište u Zagrebu, 2016.

Božić, Josip Dobroslav. Mane hrvatskog naroda ili Hrvatsko ogledalo. Senj: Tiskara Hreljanović, 1906.

Braudel, Fernand. Civilization and Capitalism 15th-18th Century. Volume 1. The Structures of Everyday Life. The Limits of the Possible. London: William Collins Sons \& Co Ltd, 1985.

Čaklović, Miroslav. Najveći neprijatelj čovječanstva alkohol! Zagreb: Tiskara Hrv. katol. tiskovnog društva, 1908.

Dom i sviet: ilustrovani list za zabavu, pouku i viesti o dnevnih dogadjajih, javnom $i$ družtvenom životu, umjetnosti i znanosti, trgovini i obrtu, glasbi, kazalištu i modi. (Zagreb), 1892.

Dujmović Ojvan, Danijela. Alkoholna pošast: intervju, Dr. Ivan Čelić. Pristup ostvaren 30. 3. 2019. https://direktno.hr/direkt/dr-celic-za-direktno-imamo-300-tisuca-alkoholicara-najrizicnije-podrucje-je-sjeverna-hrvatska-111977/. 
Đurić, Nikola. Novi Pogledi, Izdali novogradiški trezvenjaci u korist siromašnih đaka trezvenjaka. Nova Gradiška: M. Mlađan, 1913.

“Fran Gundrum Oriovčanin”. Hrvatska enciklopedija (on-line). Leksikografski zavod “Miroslav Krleža". Pristup ostvaren 10. 8. 2015. http://www.enciklopedija.hr/natuknica. aspx?id=23789 .

Friedl, Aleš. "What Do Jokes on Alcoholics Tell us about Alcoholism”. Alcoholism: Journal on Alcoholism \& Related Addictions 48 (2012), br. 1: 23-40.

Gordon, Ernest B. Anti-Alcohol Movement in Europe. New York: Fleming H. Revell Company, 1913.

Glasnik županije Požeške (Požega), 1891.- 1919.

Gašparec-Skočić, Ljiljana. "Vinova loza i vino u povijesti, sadašnjosti i budućnosti Hrvata". Hrvatska revija 4 (2015) Pristup ostvaren 10. 3. 2019. http://www.matica.hr/hr/470/ vinova-loza-i-vino-u-povijesti-sadasnjosti-i-buducnosti-hrvata-25304/.

Heath, Dwight B. International Handbook on Alcohol and Culture. Westport; London: Greenwood Press, 1995.

Hudolin, Vladimir. Alkohološki priručnik. Zagreb: Medicinska naklada, 1991.

Izvješća upravnog odbora županije požeške (Požega), 1895.-1914.

Jančula, Julije. Povijest Cernika i cernička samostanska kronika. Slavonska Požega: “A. Tajkov", 1980.

Jandrić-Balen, Marica; Balen, Ivica. “Andrija Štampar i borba protiv alkoholizma”. U: Andrija Štampar. Knjiga I.: Mladost Andrije Štampara (1888.-1919.), priredili Ivica Balen i Stana Vukovac, 85-94. Osijek; Slavonski Brod: Sveučilište Josipa Jurja Strossmayera u Osijeku; Opća bolnica “Dr. Josip Benčević” Slavonski Brod, 2006.

Kostić, Milan. Alkohol, kriminalitet i pravo. Zagreb: Dionička tiskara, 1912.

Krašić, Wollfy. "Djelovanje kapucinskog protualkoholnog društva 'Sveta vojska”. Historijski zbornik 67 (2014), br. 1: 129-149.

Lakatoš, Josip. Industrija Hrvatske i Slavonije. Zagreb: Jugoslavenski Lloyd, 1924.

Narodne novine (Zagreb), 1861. - 1945.

Nezavisnost, Bjelovarsko-križevački vjesnik(Bjelovar), 1906. - 1935.

Novi naraštaj, list za suzbijanje opojnih pića, za školu i dom (Zagreb), 1906. - 1914.

Novi život: glasilo Društva apstinenata u Hrvatskoj i Slavoniji (Karlovac), 1913. - 1921.

Oriovčanin, Fran Gundrum. Alkohol-otrov! Bjelovar: Lav Weiss, 1904.

Piller, Matija; Mitterpacher, Ljudevit. Putovanje po Požeškoj županiji u Slavoniji 1782. god. Požega; Osijek: Matica hrvatska, 1995.

Prva izložba dalmatinsko-hrvatsko-slavonska 1864. mjeseca kolovoza, rujna i listopada obdržavana u Zagrebu glavnome gradu Trojedine kraljevine. Zagreb: Antun Jakić, 1864.

Pokret, glasilo hrvatskih naprednjaka (Zagreb), 1904. - 1910.

Radnički Glasnik: list za interese hrv. radničkog staleža (Zagreb), 1887. - 1889. 
Statistički godišnjak Kraljevine Hrvatske i Slavonije I. 1905. Zagreb: Kr. zemaljski statistički ured, 1913.

Studen, Alen. Pijane zverine. O moralni in patološki zgodovini alkoholizma na Slovenskem $v$ dobi meščanstva. Celje: Zgodovinske društvo, 2009.

Štifanić, Mirko. “Alkoholizam i društvene znanosti”. Društvena istraživanja 4 (1995), br. 4-5: 703-719.

Unwin, Tim. Wine and the Vine: An Historical Geography of Viticulture and the Wine Trade. London; New York: Routledge, 1991.

Vinogradarski i voćarski viestnik: ilustrovani časopis za vinogradarstvo, voćarstvo i pivničarstvo, te za promet voćem i vinom (Zagreb), 1898.

Vukovac, Stana. “Zrnje iz života Andrije Štampara Andrija Štampar vizionar i praktičar”. Priopćenje na znanstvenom skupu: Štamparova načela i suvremeni zdravstveni izazovi, Škola narodnog zdravlja “Andrija Štampar”, Medicinski fakultet Sveučilišta, Zagreb, Hrvatska 3. i 4. 10. 2008. Pristup ostvaren 5. 8. 2015., www.hcjz.hr/index.php/hcjz/article/ download/952/911.

“Temperance Movement”. Pristup ostvaren 14. 11. 2015., https://en.wikisource.org/wiki/ Catholic_Encyclopedia_\%281913\%29/Temperance_Movements.

Zoričić, Milovan. “Žiteljstvo Kraljevina Hrvatske i Slavonije po zvanju i zanimanju”. Rad JAZU, knjiga 125. Zagreb: JAZU, 1896.

Zvekan: humoristički list (Zagreb), 1889. - 1903.

Žebčević Matić, Maja. Vinogradarstvo i vinarstvo u požeškom kraju krajem 19. i početkom 20. st. Gradski muzej Požega, 18. svibnja - 15. rujna 2010.: etnografska izložba povodom Međunarodnog dana muzeja - 18. svibnja. Požega: Gradski muzej Požega, 2010. 


\section{PRILOZI}

$$
\begin{gathered}
\text { Promjena vremena po Falbu. } \\
\text { (U } 3 \text { slike). }
\end{gathered}
$$

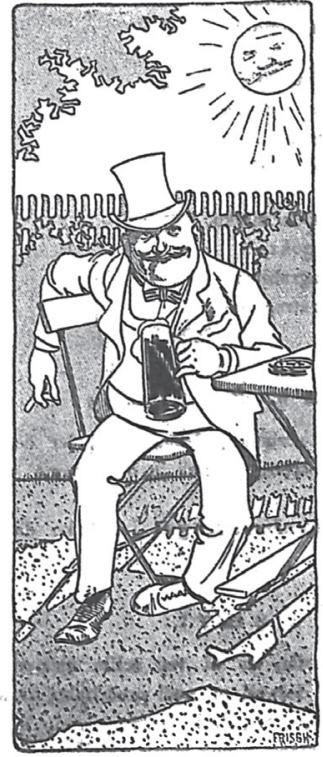

Dan je ponajprije vilo vedar.

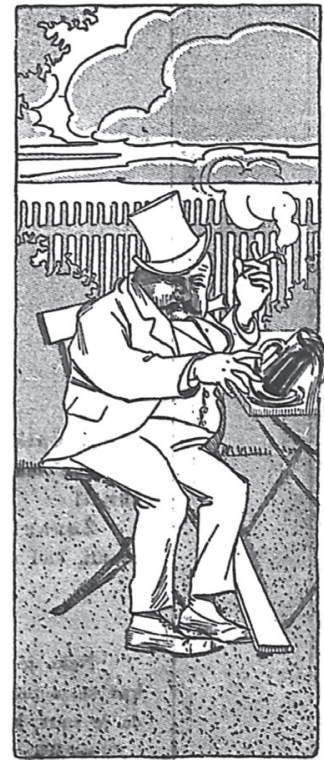

Zatim malko naoblačen.

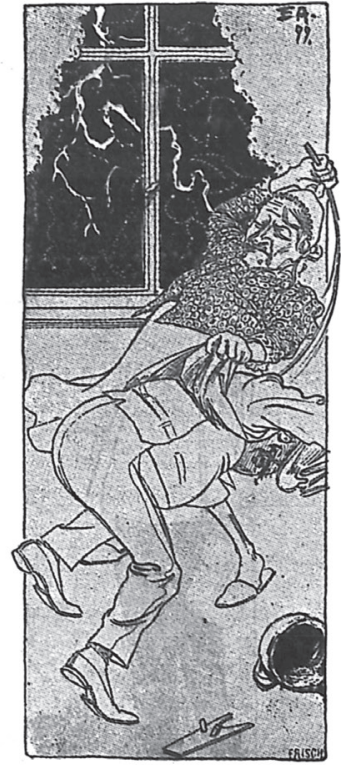

A na večer pada jaka tuča.

Slika 1. Promjena vremena po Falbu, karikatura, Zvekan, 1890.

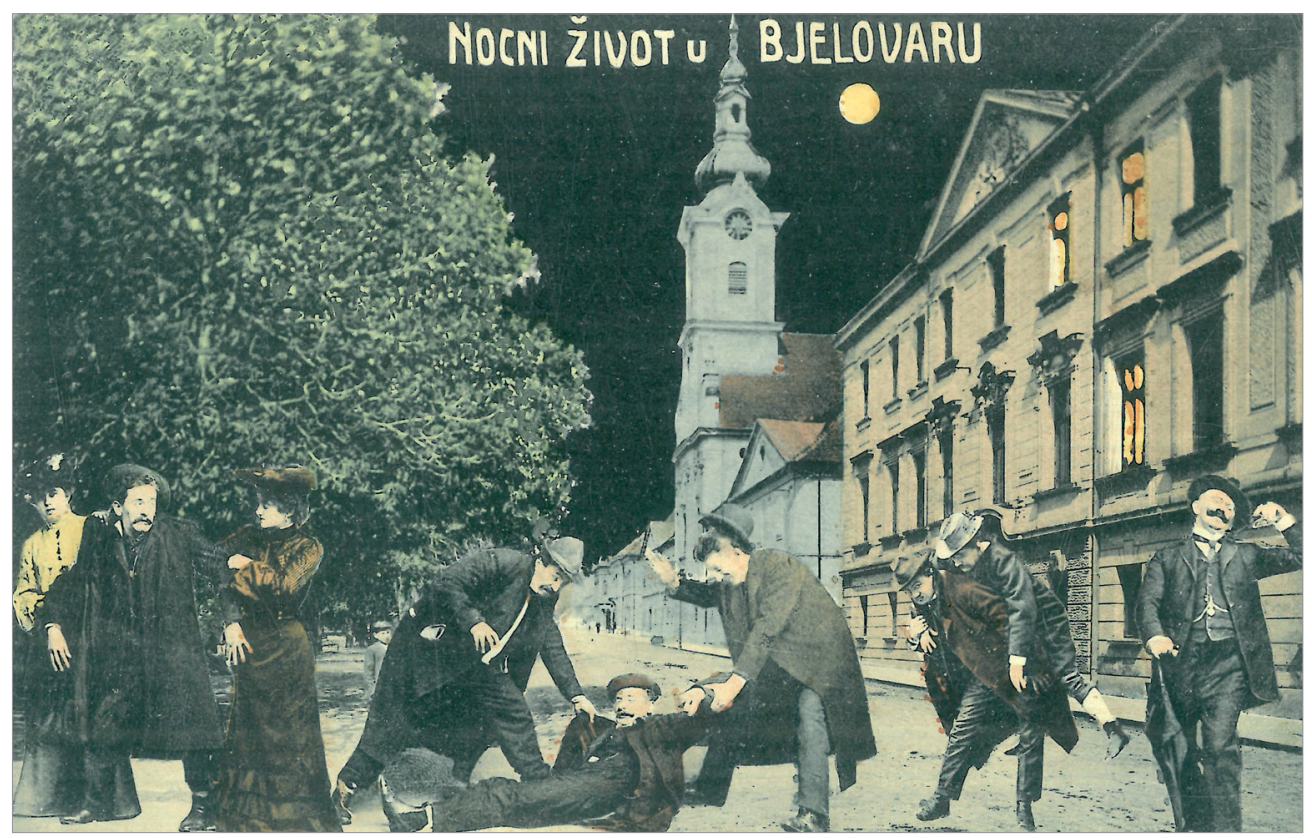

Slika 2. Noćni život u Bjelovaru, razglednica oko 1910. 


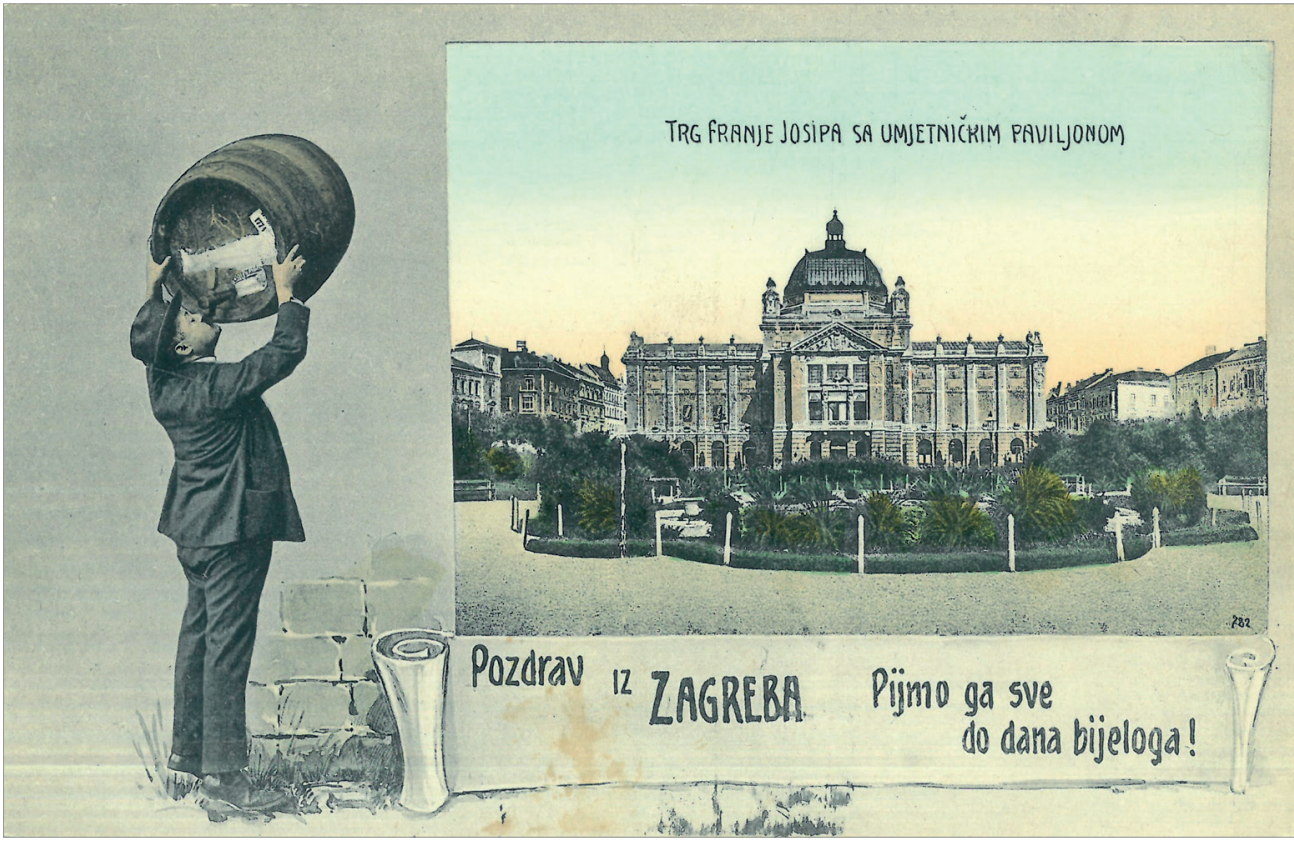

Slika 3. Pozdrav iz Zagreba. Pijmo ga sve do dana bijeloga!, razglednica, 1908.

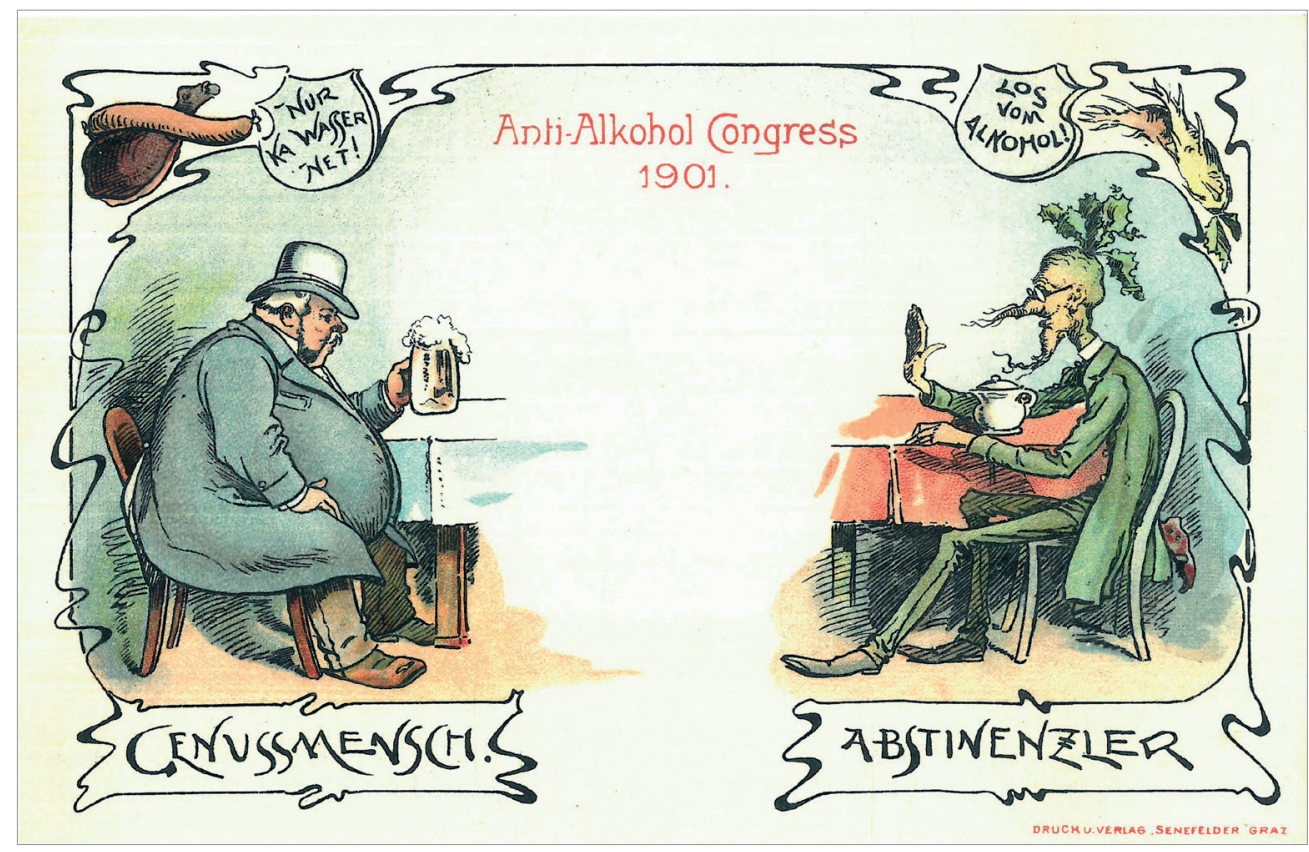

Slika 4. Anti-Alkohol Congress 1901., razglednica, 1901. 
Iva Salopek Bogavčić*

\section{On Alcoholism and Anti-Alcohol Measures in the Triune Kingdom during the Early $20^{\text {th }}$ Century}

\section{Summary}

Based on an analysis of archival material, newspapers, and the magazines "New Generation" and "New Life", the article examines the problem of alcoholism and the beginning of struggle against it before 1914 in the Kingdom of Croatia and Slavonia and the Kingdom of Dalmatia. Modern anti-alcohol action started in the Slavonian area, where the devastating consequences of drinking alcoholic beverages were observed on many occasions. The custom of drinking alcoholic beverages had been present there since old times due to tradition, hard work, and agricultural crops, but it was only with the grapevine diseases and the industrial production of alcoholic beverages that the fragile balance in the moderation of drinking was disturbed. The problem of excessive consumption of alcohol and its harmful consequences for individuals and the society alike was diagnosed almost simultaneously by Fran Gudrum Oriovčanin, Nikola Đurić, and Andrija Štampar, who critically identified the problem and indicated its seriousness in numerous scholarly publications, also launching two magazines on the subject. As early as 1904, Fran Gudrum Oriovčanin wrote about the harmfulness of alcoholic beverages and in 1906, together with Nikola Đurić, he launched the first anti-alcohol magazine and developed a program to combat alcoholism. The article examines the emergence of the earliest abstinence societies, the social stereotypes about alcohol, and the first statistical evaluations of the impact of alcoholism on the society. The foundations for the Society of Abstainers in the Kingdom of Croatia and Slavonia were laid as early as 1906, but its formal activities started only in 1912. The Society based its work on the insights of modern science and statistics, trying to change the stereotypes and popular customs in cooperation with the social elite by publishing articles, leaflets, and brochures, organizing subsidiary branches and lectures. The culmination of the Society's activities was an anti-alcohol exhibition held in 1914 at the Art Pavilion in Zagreb, as well as participation of a Croatian representative at the 4th Austrian Anti-Alcohol Congress in Brno. The Society approached alcoholism as a disease of individuals, families, and communities that must be cured with the participation of all partakers and interested parties, thus confirming that its anti-alcohol policy before World War I was in line with the progressive European anti-alcohol tendencies.

Keywords: alcohol, alcoholism, Anti-Alcohol Measures, Andrija Štampar, Fran Gudrum Oriovčanin

Iva Salopek Bogavčić, 10000 Zagreb, Croatia, E-mail: iva.salopek.bogavcic@gmail.com 